\title{
A tribo Tageteae (Asteraceae) no sul do Brasil
}

\author{
Camila Rezendo Carneiro' \& Mara Rejane Ritter ${ }^{1,2}$
}

\begin{abstract}
1. Universidade Federal do Rio Grande do Sul, Instituto de Biociências, Programa de Pós Graduação em Botânica Av. Bento Gonçalves 9500, Prédio 43433. CEP 91501-970, Porto Alegre, RS, Brasil.milarezendo@yahoo.com.br 2. Universidade Federal do Rio Grande do Sul, Instituto de Biociências, Departamento de Botânica, Av. Bento Gonçalves 9500, Prédio 43432. CEP 91501-970, Porto Alegre, RS, Brasil.
\end{abstract}

Recebido em 04.V.2016

Aceito em 10.VII.2018

DOI 10.21826/2446-8231201873204

RESUMO - A tribo Tageteae é composta predominantemente por ervas e subarbustos, a maioria com glândulas oleíferas translúcidas nas folhas e brácteas involucrais. Nosso objetivo foi realizar o estudo das espécies desta tribo nos três estados da Região Sul do Brasil. Para esse estudo foram realizadas expedições de coleta, revisão bibliográfica acerca dos táxons envolvidos e análise de material depositado em 19 herbários das Regiões Sul e Sudeste do Brasil, além de imagens de exsicatas de herbários do exterior. São apresentadas descrições dos gêneros e espécies ocorrentes na Região Sul, chaves de identificação, dados sobre habitat, distribuição geográfica, período de florescimento e frutificação, além de fotografias, ilustrações e comentários taxonômicos e nomenclaturais adicionais. Foram consideradas 12 espécies pertencentes a três gêneros, sendo dez de ocorrência natural e duas cultivadas. O gênero mais numeroso é Porophyllum Guett., com sete espécies.

Palavras-chave: Aliança Heliantheae, Compositae, taxonomia, vegetação campestre

ABSTRACT - Tribe Tageteae in southern Brazil. The tribe Tageteae is predominantly composed by herbs and subshrubs, most with pellucid oil glands in the leaves and involucral bracts. Our aim was to study specimens of the tribe in the three state of southern Brazil. For this study, we collected specimens and we reviewed herbarium exsicata from 19 herbaria of southern and southeastern Brazil, in addition to images of exsicata from foreign herbaria. We provide descriptions of genera and species from southern Brazil, identification keys, data on habitat, geographical distribution, flowering and fruiting period, as well as photographs, illustrations and taxonomic and additional nomenclatural comments. Twelve species from three genera were considered, ten are native and two cultivated. The largest genus is Porophyllum Guett., with seven species.

Keywords: Compositae, grasslands, Heliantheae Alliance, taxonomy

\section{INTRODUÇÃO}

Tageteae pertence à subfamília Asteroideae e faz parte de um grande clado conhecido como "Heliantheae Alliance" (Panero 2007a), o qual é composto por treze tribos, incluindo Heliantheae s.s e Eupatorieae. Já no primeiro esquema de classificação de tribos em Asteraceae, proposto por Cassini (1816), "Tageteae" aparece como um grupo delimitado, sem status taxonômico definido, sob a denominação "Tagétinées", inserido na tribo Heliantheae (Bremer 1994, Baldwin 2009). Quando as tribos de Asteraceae foram formalmente descritas pela primeira vez, por Cassini (1819), esse grupo passou à categoria de tribo (sob "Tagétinée"). Posteriormente, Bentham (1873) dividiu a família em treze tribos e os integrantes da tribo Tageteae passaram a fazer parte da tribo Helenieae ("Helenioideae"). Entretanto, por volta da segunda metade do século XX, alguns autores, considerando ser a tribo Helenieae um grupo não natural, começaram a propor o desmembramento da mesma em diferentes conformações. Mesmo assim, embora houvesse divergência entre diferentes autores, Helenieae permaneceu consolidada, de modo geral, desde a classificação de Bentham (1873), até recentemente, na classificação de Bremer (1994), embora esse autor deixe claro que a aceitação de Helenieae seja provisória, por motivos práticos. Atualmente, os táxons contidos em Helenieae l.s. encontram-se divididos em seis tribos (Baldwin et al. 2002), entre elas Helenieae s.s. e Tageteae, a qual é abordada neste trabalho.

Na proposta de Baldwin et al. (2002), Tageteae é restabelecida, porém com uma circunscrição mais ampla em relação às classificações anteriores. Assim, a tribo, como atualmente circunscrita, apresenta 32 gêneros e cerca de 270 espécies do Novo Mundo (apenas uma espécie do gênero Flaveria Juss. é australiana), de regiões temperadas a tropicais, a maioria delas do sudoeste dos Estados Unidos e México, apesar da América do Sul conter também um importante número de espécies. Na circunscrição atual, são reconhecidas cinco subtribos, quatro delas com representantes sem glândulas e apenas uma, Pectidinae, ou "Tageteae Núcleo" (a maior delas), cujos representantes apresentam glândulas oleíferas translúcidas nas folhas e brácteas involucrais e compostos químicos secundários distintos, o que lhes confere um odor característico (Panero 
2007b, Funk et al. 2009) e aparentemente servem como defesa contra a herbivoria (Funk et al. 2009).

Como nem todos os representantes possuem glândulas oleíferas, as quais geralmente são ovais ou lineares, os caracteres morfológicos que sustentam os achados moleculares são os apêndices da antera bastante esclerificados, as cipselas com fitomelanina, estriadas e com carpopódio bem desenvolvido e o pápus geralmente cerdoso.

O estudo teve por objetivo realizar o levantamento, descrição e coleta de informações ecológicas das espécies pertencentes à tribo Tageteae (Asteraceae) na Região Sul do Brasil, permitindo a avaliação do estado de conservação das mesmas.

\section{MATERIAL E MÉTODOS}

Foi realizada revisão bibliográfica acerca dos táxons envolvidos, expedições de coleta e análise de material coletado em campo ou depositado em herbários. Foram analisadas exsicatas provenientes dos seguintes herbários das regiões Sul e Sudeste do Brasil (acrônimos segundo Thiers [continuamente atualizado]: ESA, FLOR, FURB, HAS, HB, HBR, HCF, HUCS, HURG, HVAT, IAC, ICN, MBM, MPUC, PACA, PEL, SMDB, SP e UPCB. Foram também analisadas imagens enviadas pelos herbários $\mathrm{BAB}$, CORD e LP, além de imagens disponíveis on line (incluindo materiais-tipo), dos herbários BR, GH, K, LINN, NY, P, $\mathrm{RB}, \mathrm{S}, \mathrm{SI}$ e US. Foram consultadas as descrições originais de todas as espécies levantadas e analisadas as imagens (em alguns casos, espécimes) de todos os exemplares-tipo, com exceção de Tagetes erecta L., cujo lectótipo consta estar depositado no herbário LINN (Howard 1989), porém não foi encontrado no catálogo virtual.

As expedições de coleta contemplaram quase todas as regiões fisiográficas do Rio Grande do Sul (Fortes 1959), à exceção da Encosta Superior do Nordeste, tendo sido também percorridas diferentes regiões dos estados de Santa Catarina e Paraná. O material-testemunho do estudo foi depositado no herbário ICN, da Universidade Federal do Rio Grande do Sul. Nas descrições foram utilizados no mínimo 10 exemplares de cada espécie ou todo o material disponível quando em quantidade inferior a esta. Os exemplares foram analisados em microscópio estereoscópico e medidos com paquímetro digital. A terminologia descritiva baseou-se em Font Quer (1979), Harris \& Harris (2001), Gonçalves \& Lorenzi (2007), Roque \& Bautista (2008) e Beentje (2010). A tribo e os gêneros foram descritos com base na literatura consultada (Cabrera 1974, Petenatti \& ArizaEspinar 1997, Panero 2007b). A descrição da tribo, por se tornar muito abrangente ao se considerar todos os representantes, baseia-se apenas nas características dos representantes locais.

Informações relativas ao habitat, distribuição geográfica, floração e frutificação foram baseadas em observações no campo e em dados bibliográficos e de etiquetas de exsicatas de herbário. As espécies foram avaliadas quanto ao estado de conservação, segundo os critérios da International Union for Conservation of Nature (IUCN 2013).

Os hábitos ou ramos foram ilustrados de forma esquemática, utilizando-se espécimes e fotografias e observando-se as proporções, e as ilustrações dos detalhes foram realizadas com a utilização de câmara-clara. As ilustrações foram feitas pela artista Anelise Scherer de Souza Nunes, com exceção de Porophyllum spathulatum C.R.Carneiro \& A.A.Schneid., ilustrado pela bióloga Márcia Vignoli da Silva.

Apenas um exemplar de cada estado externo à área de estudo foi selecionado e, no caso de haver coletas em municípios muito próximos, apenas um dos registros foi mantido, privilegiando as coletas mais recentes. As citações das obras originais e autores seguem o sítio do IPNI (2014), baseado em Brummitt \& Powell (1992).

No caso das espécies exóticas cultivadas do gênero Tagetes L., as quais foram incluídas na chave de identificação, foram utilizados dados bibliográficos (Rydberg 1915 e Gandhi \& Thomas 1989).

\section{RESULTADOS E DISCUSSÃO}

Na Região Sul do Brasil, a tribo Tageteae está representada pelos gêneros Porophyllum Guett. e Tagetes L., ambos pertencentes à subtribo Pectidinae, além de uma espécie do gênero Jaumea Pers., pertencente à subtribo mogenérica Jaumeinae. A seguir é apresentado o tratamento taxonômico referente à tribo, aos três gêneros e dez espécies nativas levantadas na área de estudo, além de chaves de identificação.

Tribo Tageteae Cass., J. Phys. Chim. Hist. Nat. Arts 88: 162. 1819.

Ervas ou subarbustos, anuais ou perenes. Folhas alternas ou opostas, lâmina foliar filiforme a amplamente ovalada, simples, frequentemente com glândulas pelúcidas marginais espalhadas. Capítulos discoides ou radiados, em sinflorescências terminais laxas, às vezes solitários. Invólucro cilíndrico, turbinado, campanulado ou hemisférico; brácteas involucrais 1-5 séries, subiguais ou graduais, livres ou variadamente fusionadas, com glândulas pelúcidas ovais ou lineares, às vezes sem glândulas. Receptáculo plano a cônico, epaleáceo, por vezes alveolado. Flores do raio pistiladas, corola amarela a vermelha, dois ou três lobos. Flores do disco monoclinas, corola geralmente actinomórfica, pentâmera. Antera com apêndices fortemente esclerificados, geralmente sem tricomas glandulares. Ramos do estilete com ápice truncado, deltado ou acuminado, geralmente papiloso, recurvado na maturidade. Cipselas cilíndricas a estreitamente fusiformes, estriadas, às vezes comprimidas, com camada de fitomelanina, negras ou marrons, esparsa a densamente pubescentes, carpopódio geralmente bem desenvolvido, conspícuo. Pápus com poucas a muitas aristas, escamas ou cerdas. 


\section{Chave de identificação para os gêneros da Tribo Tageteae da Região Sul do Brasil}

1. Plantas com glândulas oleíferas nas folhas e brácteas involucrais

1'. Plantas sem glândulas oleíferas nas folhas e brácteas involucrais 1 Jaumea (1.1 Jaumea linearifolia)

2. Folhas alternas (às vezes alternas e opostas no mesmo indivíduo), inteiras. Invólucro com brácteas livres ou fusionadas apenas na base, capítulos discoides, pápus cerdoso 2 (Porophyllum)

2 '. Folhas opostas e pinatissectas. Invólucro com brácteas fusionadas, capítulos radiados, pápus formado por aristas e escamas 3 (Tagetes)

\section{Jaumea Pers., Syn. Pl. [Persoon] 2(2): 397. 1807.}

Ervas perenes ou subarbustos decumbentes, glabros. Folhas opostas, inteiras, lâminas lineares a cilíndricas, suculentas. Capítulos radiados ou discoides, terminais, solitários, pedunculados. Invólucro cilíndrico a campanulado; brácteas involucrais em 3-4 séries graduais, herbáceas, suculentas. Receptáculo cônico, sem páleas. Flores do raio, quando presentes, com corola amarela, ápice levemente trilobado. Flores do disco tubulosas, corola amarela, glabra, lobos espessados. Apêndices apicais da antera ovalados ou deltados, glabros, base obtusa. Ramos do estilete curtos, com ápice deltóide, papiloso. Cipselas cilíndricas, conspicuamente estriadas, estreitadas na base, pretas ou marrons, glabras, carpopódio curto, cilíndrico. Pápus com várias aristas ou ausente.

Jaumea compreende duas espécies (Panero 2007b): uma norte-americana, Jaumea carnosa (Less.) A.Gray, distribuída pela costa oeste dos Estados Unidos e noroeste do México e uma sul-americana, Jaumea linearifolia (Juss.) DC., com ocorrência na Argentina, no Uruguai e no sul do Brasil (Rio Grande do Sul).

\subsection{Jaumea linearifolia (Juss.) DC., Prodr. [A. P. de Candolle] 5: 663. 1836.}

(Figs. 1 A-D; Fig. 6 A)

Ervas perenes decumbentes, rizomatosas, $17-58 \mathrm{~cm}$ compr., pouco ramificadas, homoicas, ramos ascendentes 10-15 cm alt,. ramos cilíndricos, entrenós evidentes. Folhas opostas, sésseis, lâminas, $18-57$ x 2,2-5 mm, lineares, crassas, verde-claras, ápice foliar agudo ou obtuso-mucronado, bases conadas, margem inteira, glabras, uninervadas ou trinervadas, sem glândulas. Capítulos discoides, 30-40 flores; pedúnculos 12,5-44,8 mm compr., não engrossados no ápice, nutantes em fase imatura dos capítulos. Invólucro 8,4-12,2 x 5,2-8 mm, campanulado, imbricado, 3-4 séries desiguais, brácteas progressivamente mais longas e estreitas, adpressas, livres, subrotundas a ovaladas, ápice arredondado, curvadas, glabras, verdes, externas 2,9-8 x 3-10 mm, intermediárias 5,2-9 x 5,9-6,5 mm, internas 8,5-9,4 x 2,7-5 $\mathrm{mm}$. Receptáculo 2-3,5 mm diâm, convexo, alveolado. Flores isomorfas monoclinas, corola ca. 5,5 x 1,2 mm, amarela; tubo da corola discreta e uniformemente dilatado em direção ao ápice, glabro, ápice pentalobado, lobos ca. 0,7 x 0,6 mm, agudos. Anteras 2-2,3 mm compr., amarelas, apêndices do conetivo agudos, apêndices basais curtamente sagitados. Estilete 5,4 mm compr.; ramos 0,8-0,9 mm compr., retos, ápice alargado. Cipselas 3-3,5 $\mathrm{mm}$ compr., oblongas, fortemente 10 -estriadas, marromclaras, carpopódio inconspícuo. Pápus 1,3-1,9 mm compr, aristas setáceas ciliadas subiguais.

Distribuição geográfica: no Brasil, a espécie teve sua ocorrência recentemente registrada, no Rio Grande do Sul, em áreas estuarinas dos municípios de São José do Norte e Chuí (Cordazzo et al. 2007). É encontrada também no Uruguai e na Argentina, na província de Buenos Aires (Lombardo 1983).

Habitat: espécie halófita de grande especificidade por solos arenosos ou lodosos de áreas estuarinas e planícies inundáveis com influência marinha (água salobra).

Observações: resistente à variação de salinidade e a alagamentos temporários, essa espécie floresce do final da primavera ao início do outono (Cordazzo et al. 2007). Segundo os critérios da IUCN, enquadra-se na categoria "criticamente em perigo" (CR), sob os critérios B1ab(iii), uma vez que apresenta extensão de ocorrência muito pequena e habitat muito específico, o que torna sua distribuição fragmentada, esse habitat também estando sujeito ao declínio da qualidade, principalmente devido à poluição.

Material examinado: BRASIL, RIO GRANDE DO SUL, Chuí, 33S45', 53W22', na margem do Arroio Chuí, 9.III.2005, C. Costa \& V.L. Caetano $s / n^{\circ}$ (HURG 4034); 33S44', 53W22', Barra do Chuí, sob a ponte, 16.XI.2013, C.R. Carneiro 70 (ICN); São José do Norte, 32S09', 52W04', Barra Molhe Leste, 18.III.2005, C. Costa \& J. Marangoni $\mathrm{s} / \mathrm{n}^{\circ}$ (HURG 4035); ibidem, 25.I.2014, C. Carneiro 74 (ICN).

2 Porophyllum Guett., Hist. Acad. Roy. Sci. Mem. Math. Phys. (Paris, $4^{\circ}$ ) 1750: 377. 1754.

Ervas, subarbustos ou arbustos, anuais ou perenes, geralmente glabras, fortemente aromáticas, homoicas ou ginodioicas. Folhas simples, inteiras, alternas, opostas ou ambas, pecioladas ou sésseis, lâmina ampla a filiforme, com glândulas oleíferas translúcidas ao longo da margem e às vezes também dispersas pelo limbo. Capítulos discoides, homógamos, terminais, pedunculados, solitários ou em cimeiras corimbiformes ou paniculiformes. Invólucro cilíndrico ou campanulado, unisseriado, 5-9 brácteas involucrais livres ou fusionadas apenas na base, glândulas lineares em duas séries longitudinais dispostas no centro da bráctea. Receptáculo plano ou levemente convexo. Flores 

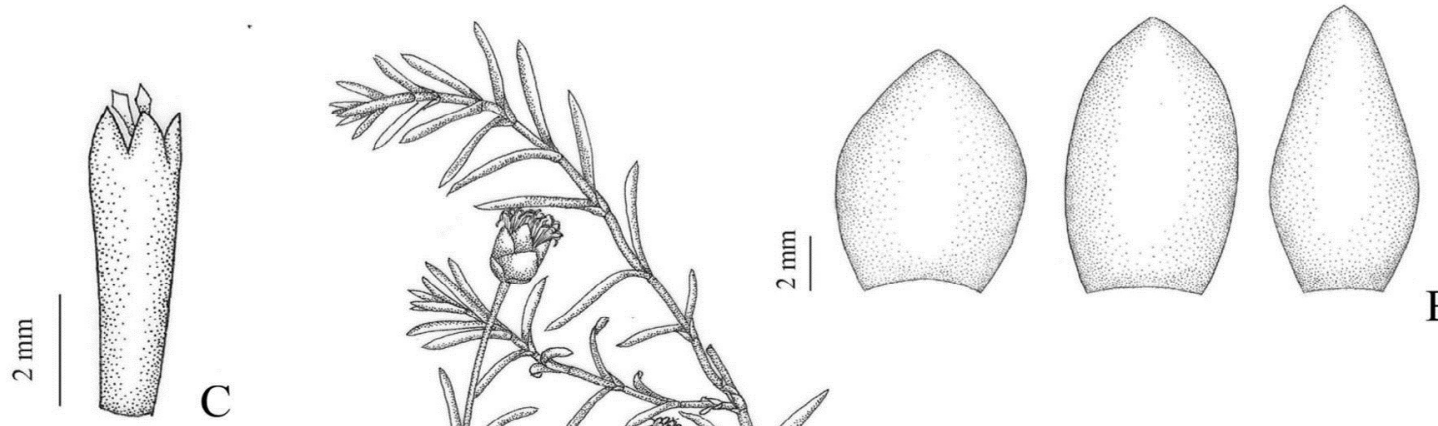

B

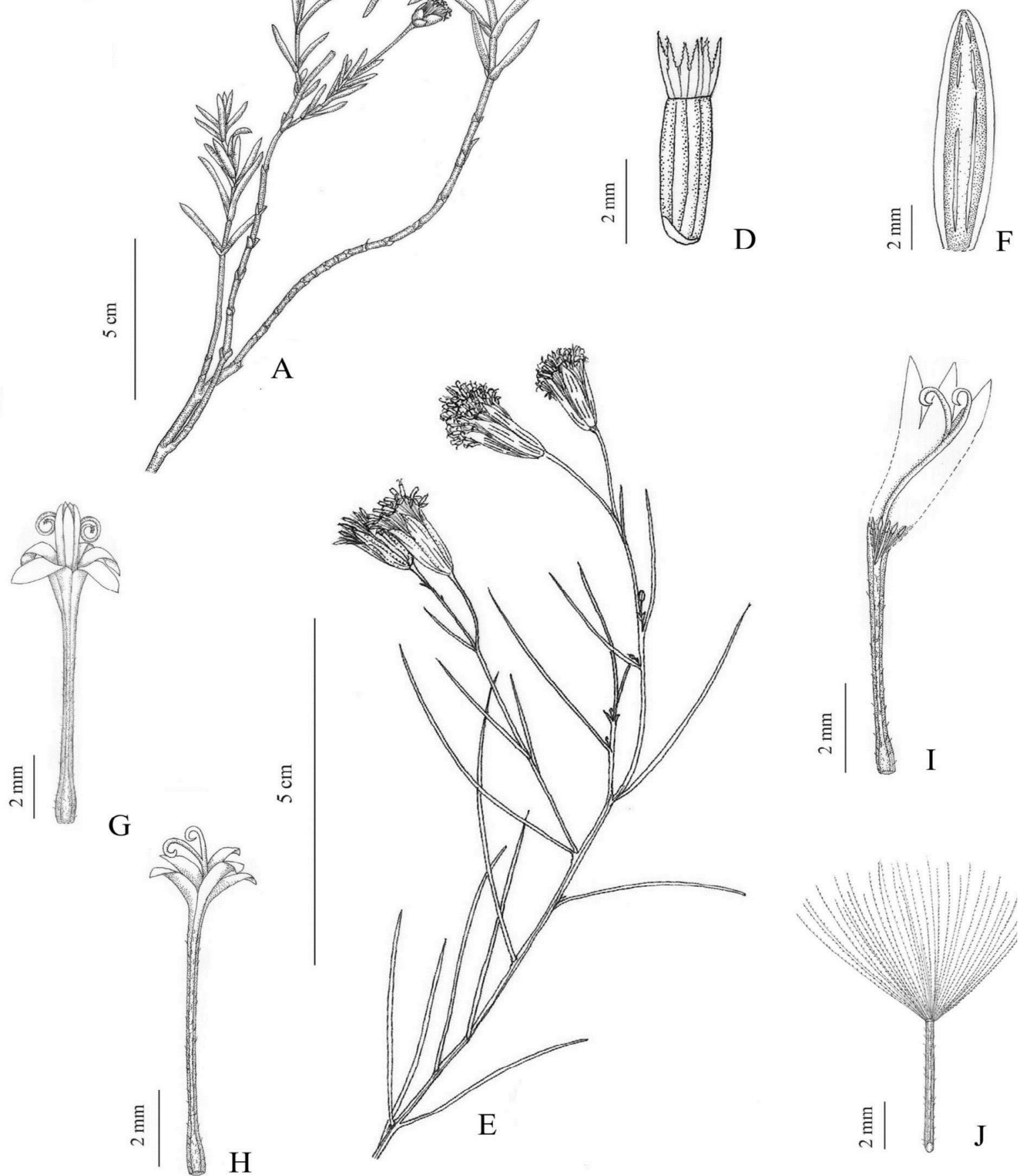

Figs. 1. A-J. A-D. Jaumea linearifolia (Juss.) DC. A. Detalhe do ramo; B. Brácteas involucrais, da esquerda para a direita (externa, intermediária, interna); C. Flor; D. Cipsela, pápus (A-D. C.R. Carneiro 74, ICN). E-J. Porophyllum angustissimum Gardner. E. Detalhe do ramo; F. Bráctea involucral; G. Flor monoclina; H. Flor pistilada; I. Flor pistilada aberta mostrando os estaminódios; J. Cipsela e pápus. (E-G. C.R. Carneiro 57, ICN. H-J. C.R. Carneiro 40, ICN). 
monoclinas ou pistiladas (nunca com os dois tipos no mesmo indivíduo), corola tubulosa estreita, actinomórfica, amarelada, esverdeada ou arroxeada, pentalobada, ápices dos lobos da corola alargados. Anteras com apêndices apicais agudos e apêndices basais obtusos ou sagitados. Estilete com ramos longos, afilados, papilosos, recurvados. Cipselas fusiformes, estreitas, estriadas, marrons ou negras, puberulentas ou hispidulosas, raramente glabras, carpopódio asssimétrico (Roque \& Bautista, 2008). Pápus com numerosas cerdas livres, amareladas, arroxeadas ou avermelhadas.

Porophyllum é um gênero americano, distribuído do sudeste dos Estados Unidos até o centro da Argentina (Petenatti \& Ariza-Espinar 1997), apresentando atualmente cerca de 30 espécies (Panero 2007b). No Brasil existem nove espécies (Carneiro, C.R. 2018). Cabrera (1974) cita quatro espécies para o sul do Brasil, embora Petenatti \& Ariza-Espinar (1997) apontem a ocorrência de mais uma, Porophyllum angustissimum Gardner. Nesse trabalho, essas cinco espécies são confirmadas, somando-se a elas mais duas: uma delas restabelecida, Porophyllum curticeps Malme, e outra descrita recentemente por Carneiro et al. (2014), Porophyllum spathulatum C.R.Carneiro \& A.A.Schneid.

A única revisão taxonômica do gênero é a de Jonhson (1969), embora, como apontam Petenatti \& Ariza-Espinar (1997), as espécies sul-americanas não tenham sido satisfatoriamente resolvidas. O centro de distribuição e provável centro de origem é o México ou América Central, segundo Jonhson (1969), porém essa hipótese precisa ser testada com estudos evolutivos e biogeográficos. As características que, em conjunto, separam Porophyllum de outros gêneros a ele relacionados são a presença de capítulos discoides, pápus cerdoso e folhas bem desenvolvidas.

Embora o número de brácteas involucrais possa variar de 5 a 9 no gênero, as espécies que ocorrem na área de estudo apresentam sempre 5. Além disso, todas essas, com exceção de Porophyllum ruderale (Jacq.) Cass., são ginodioicas. A ginodioicia em Porophyllum é pouco conhecida e, após a constatação de que esse sistema sexual ocorre em quase todas as espécies presentes na área de estudo, verificou-se que apenas na Flora Fanerogâmica Argentina (Petenatti \& Ariza-Espinar 1997) esse assunto foi tratado, com esse sistema sexual sendo citado para algumas espécies do gênero.

\section{Chave de identificação para as espécies do gênero Porophyllum da Região Sul do Brasil}

1. Folhas filiformes, lineares ou estreito-oblanceoladas ..

..................................................................... 2

1'. Folhas lanceoladas, elípticas, estreito-elípticas, espatuladas ou obovaladas... ... 4

2. Subarbustos até $25 \mathrm{~cm}$ de altura, capítulos solitários, pedúnculos longos (mínimo $4 \mathrm{~cm}$ compr.)

2.4 Porophyllum linifolium
2'. Ervas ou subarbustos geralmente com mais de $25 \mathrm{~cm}$ de altura, folhas dispostas até o ápice da planta, capítulos normalmente em sinflorescências (raramente solitários), pedúnculos curtos, geralmente até $1,2 \mathrm{~cm}$ compr., atingindo no máximo $2,6 \mathrm{~cm}$ compr. ... 3 3. Plantas com raiz pivotante, caule geralmente ramificado, folhas filiformes, $12-56 \times 0,25-1(1,5) \mathrm{mm}$....

\subsection{Porophyllum angustissimum}

3'. Plantas com xilopódio, caule não ramificado ou pouco ramificado na base, ramificando-se no ápice, folhas lineares, 11-20 x 0,65-1,1 mm, às vezes também linear-lanceoladas, 42-73 x 1,4-3,5 mm ................. 2.5 Porophyllum obscurum 4. Ervas, folhas elípticas, estreito-elípticas ou obovaladas, brácteas involucrais lineares, 17-21 mm compr., ápice acuminado

2.6 Porophyllum ruderale subsp. ruderale 4'. Subarbustos, folhas elípticas, lanceoladas ou espatuladas, brácteas involucrais lineares ou linear-oblongas com menos de $17 \mathrm{~mm}$ compr., ápice triangular, agudo ou obtusomucronado .... 5 5. Plantas decumbentes, folhas espatuladas 2.7 Porophyllum spathulatum 5' Plantas eretas ou ascendentes, folhas nunca espatuladas 6. Plantas com raiz pivotante, brácteas involucrais fortemente vináceas, flores amarelo-vináceas

2.2 Porophyllum curticeps

6' Plantas com xilopódio ou rizoma, brácteas involucrais esverdeadas ou levemente vináceas, flores amarelo-claras 2.3 Porophyllum lanceolatum

2.1 Porophyllum angustissimum Gardner, London J. Bot. 7: 410. 1848.

(Figs. 1 E-J; Fig. 6 B)

Subarbustos perenes, eretos, ascendentes ou decumbentes, $25-90 \mathrm{~cm}$, ginodioicos; raiz pivotante profunda; caule cilíndrico, estriado, divaricadoramificado desde a base ou apenas na porção superior. Folhas alternas, sésseis, lâminas 12-56 x 0,25-1 $(1,5) \mathrm{mm}$, filiformes, crassiúsculas, verde-claro a verde-escuras, ápice arredondado ou obtuso, base atenuada, margem inteira, glabras, uninervadas, glândulas 1,1-1,5 mm compr., lineares, pouco visíveis. Capítulos isolados ou em sinflorescências terminais corimbiformes de 2-3 capítulos por ramo. Capítulos com 15-38 flores; pedúnculos 1,911,9 (14-26) mm compr., pouco engrossados no ápice. Invólucro cilíndrico, 5 brácteas livres, 10-14 (16,3) x 1,152,4 mm, linear-acuminadas ou linear-oblongas, ápice agudo ou triangular, planas ou levemente curvadas, esverdeadas, glabras, bordas hialinas com glândulas longas, às vezes quase do comprimento da bráctea. Receptáculo ca. $1,5 \mathrm{~mm}$ diâm., plano, alveolado. Flores monoclinas com corola 7,9-11,8 x 0,85-1,4 mm na porção mais larga, amareloclara; tubo da corola estreito, ápice dilatado, lobos 1,6-1,9 x 0,6 mm compr., agudos. Anteras 2,1-2,2 mm compr., exsertas, amarelo-claras a alaranjadas, apêndices basais 
sagitados. Estilete 9,7-10,8 mm compr., ramos 2,7-2,9 $\mathrm{mm}$ compr. Flores pistiladas com corola 7,8-9 x 0,95$1,7 \mathrm{~mm}$ na porção mais larga, amarelo-clara; tubo da corola estreito, ápice dilatado, lobos ca. $1,3 \times 0,5 \mathrm{~mm}$, agudos. Estaminódios 5, ca. $2 \mathrm{~mm}$ compr., filiformes, ápice lanceolado, inclusos. Estilete 9-10 mm compr., ramos 1,652,05 mm compr. Cipselas 5,6-6,6 mm compr., marrons a negras, puberulentas, tricomas claros; carpopódio ca. 0,3 $\mathrm{mm}$, claro. Pápus 7,1-8,5 mm, unisseriado, cerdas amareloclaras, barbeladas.

Distribuição geográfica: no Brasil, ocorre no Distrito Federal, em Goiás, Mato Grosso, Minas Gerais, Rio Grande do Sul, onde é encontrada no litoral, e São Paulo; na Argentina, ocorre nas províncias de Misiones e Entre Rios (Zuloaga et al. 2014).

Habitat: em solos arenosos do litoral, ocorrendo nas dunas. Nos estados das Regiões Sudeste e Centro-Oeste, apesar de não apresentar distribuição litorânea, a espécie também parece estar associada a solos arenosos, conforme informações extraídas de etiquetas de exsicatas.

Observações: a espécie floresce e frutifica de novembro a abril. Segundo os critérios da IUCN, enquadra-se na categoria "em perigo", sob os critérios EN B1ab(iii) + 2ab(iii), com baixa extensão de ocorrência e baixa área de ocupação. Além disso, as populações são pequenas, esparsamente distribuídas e sujeitas a ameaças como o avanço das monoculturas de Pinus spp., ocupação urbana e exploração turística. Os exemplares dessa espécie coletados no Rio Grande do Sul que foram examinados estavam anteriormente indeterminados ou identificados como Porophyllum obscurum (Spreng.) DC. P. angustissimum difere de $P$. obscurum por ser mais ramoso e apresentar, de modo geral, folhas mais longas e estreitas (12-56 x 0,25-1 $\mathrm{mm}$, contra $11-20 \times 0,65-1,1 \mathrm{~mm}$ ou $42-73 \times 1,4-3,5 \mathrm{~mm}$, em $P$. obscurum ) e mais numerosas.

Apesar da ocorrência de P. angustissimum no Rio Grande do Sul ser citada com dúvida por alguns pesquisadores, como Malme (1931), optou-se por confirmar a ocorrência da espécie no Estado. Os espécimes procedentes das regiões CentroOeste e Sudeste analisados são citados como eretos, sendo, em geral, menos ramificados, com folhas mais estreitas, capítulos com menor número de flores e brácteas mais longas e mais estreitas, porém com variações e intervalos que se sobrepõem às medidas encontradas para os espécimes do Rio Grande do Sul. Sua ocorrência aparentemente disjunta neste estado poderia ser explicada pela continuidade através da Argentina, uma vez que essa espécie ocorre nas províncias de Misiones e Entre Rios. O fato de não haver registros de ocorrência da espécie em Santa Catarina e no Paraná pode estar relacionado à insuficiência de coletas ou a questões ambientais, como a destruição de habitats.

Material selecionado: BRASIL, GOIÁS, Alto Paraíso de Goiás, Cachoeira dos Cristais, 22.V.2008, J.M. Silva et al. 6665 (MBM). MATO GROSSO, Jaciara, Rodovia BR163, km 319, 15.V.1995, G. Hatschbach et al. 62809 (MBM).
MINAS GERAIS, Joaquim Felício, Serra do Cabral, 14.IV.1996, G. Hatschbach et al. 64712 (HB, MBM, UPCB). RIO GRANDE DO SUL, Balneário Pinhal, 30¹4'14,8”S, $50^{\circ} 15^{\prime} 3,7^{\prime}$ 'W, dunas antes da chegada na cidade pela RS040, 28.XII.2012, C.R. Carneiro 40 (ICN); Capão da Canoa, Capão Novo, 06.I.1995, N.I. Matzenbacher $s / n^{\circ}$ (ICN 106339); Cidreira, Praia de Salinas, 3.I.2003, J.L. Waechter 2680 (ICN); Osório, Fazenda do Arroio, 14.IV.1950, $B$. Rambo SJ 46767 (ICN, PACA); Tavares, Parque Nacional da Lagoa do Peixe, 13.I.1988, E. Danilevicz $s / n^{\circ}$ (HAS 21681); Viamão, Parque Estadual de Itapuã, 20.III.2013, C.R. Carneiro 57 (ICN). SÃO PAULO, Itirapina, 21.I.1999, J.L.S. Tannus \& M.A. Assis 362 (MBM).

2.2 Porophyllum curticeps Malme, Ark. Bot. 24A(6): 74. 1931.

(Figs. 2 A-G; Fig. 6 C)

Subarbustos anuais ou perenes, eretos ou ascendentes, 0,4-1 m alt., ginodioicos. Raiz pivotante. Caule cilíndrico, na porção inferior lenhoso e não ramificado, na porção superior herbáceo, estriado, ramificado. Folhas alternas ou opostas, pecioladas, uniformemente distribuídas até próximo à extremidade dos ramos; pecíolo 1,7-6,3 $(8,1)$ mm, lâminas $16,5-51,5$ x 1,8-4,1(8,3) mm, estreitolanceoladas a elípticas, membranáceas à crassiúsculas, verdes, ápice foliar agudo, às vezes obtuso-mucronado, base atenuada, margem crenada, glabras, uninervadas, glândulas 1,2-1,6 mm compr., lineares, dispostas ao longo da margem, junto às reentrâncias. Capítulos raramente isolados ou em sinflorescências terminais corimbiformes laxas de 2-4 capítulos por ramo. Capítulos 30-39 flores; pedúnculos 2,5-15 mm compr., pouco engrossados no ápice, às vezes com uma bráctea próxima ou imediatamente abaixo do capítulo. Invólucro cilíndrico, 5 brácteas livres, 9,55$11,8(13,3) \times 2,4-2,5 \mathrm{~mm}$, oblongo-lineares, ápice triangular ou agudo, curvadas, glabras, intensamente vináceas, crassas, bordas hialinas com glândulas menores do que a metade do comprimento da bráctea. Receptáculo 1,8-2 mm diâm., plano, alveolado. Flores monoclinas, corola 7,4-9,3 x 0,9-1 mm na porção mais larga, amarelo-vinácea ou esverdeadovinácea; tubo da corola estreito, ápice dilatado, lobos 1,3 x 0,5 mm, agudos. Anteras 1,35-1,9 mm compr., exsertas, rosadas, apêndices basais sagitados. Estilete 9,8-11 mm compr., ramos 2-2,55 mm compr. Flores pistiladas, corola 6,5-7,5 x 1,3 mm, amarelo-vinácea ou esverdeado-vinácea; tubo da corola estreito, ápice dilatado, lobos 1,4-1,5 x ca. $0,4 \mathrm{~mm}$, agudos. Estaminódios 5, 1,5-1,7 mm compr., filiformes, ápice lanceolado, inclusos. Estilete 7,3-8,4 mm compr.; ramos ca. $2 \mathrm{~mm}$ compr. Cipselas 5,6-7,25 mm compr., marrom-escuras, hispidulosas, tricomas claros à ferrugíneos; carpopódio 0,3 mm compr. Pápus 4,8-5,3 $\mathrm{mm}$ compr., unisseriado, cerdas amarelo-claro-douradas, frequentemente com manchas vináceas, barbeladas.

Distribuição geográfica: no Brasil, ocorre no Rio Grande do Sul, nos morros graníticos de Porto Alegre e Viamão, 


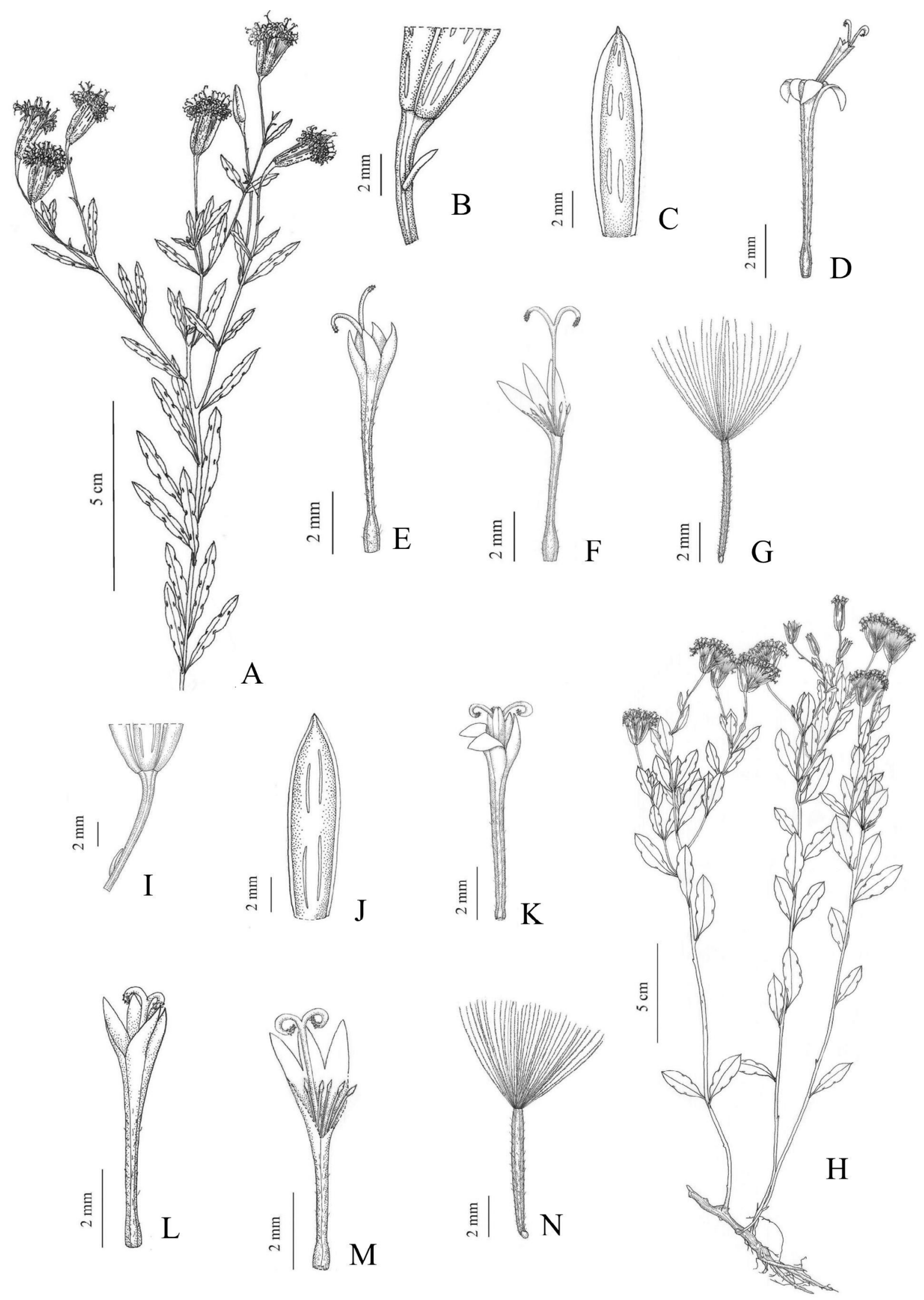

Figs. 2. A-N. A-G. Porophyllum curticeps Malme. A. Detalhe do ramo; B. Pedúnculo evidenciando posição da bráctea mais próxima ao capítulo; C. Bráctea involucral; D. Flor monoclina; E. Flor pistilada; F. Flor pistilada aberta mostrando os estaminódios; G. Cipsela e pápus (A, B, G. R. Setubal \& J. Bassi 218, ICN. C, D. C.R. Carneiro 59, ICN. E, F. C.R. Carneiro 60, ICN). H-N. Porophyllum lanceolatum DC. H. Hábito; I. Pedúnculo evidenciando posição da bráctea mais próxima ao capítulo; J. Bráctea involucral; K. Flor monoclina; L. Flor pistilada; M. Flor pistilada aberta mostrando os estaminódios; N. Cipsela e pápus. (H, I, J, K, N. C.R. Carneiro 68, ICN. L, M. C.V. Ely, ICN 192033). 
na região dos Campos de Cima da Serra, em São Francisco de Paula, e no litoral norte, em Capão da Canoa e Torres e, a partir daí, com distribuição contínua pelo litoral de Santa Catarina, até Florianópolis.

Habitat: segundo observações de campo, ocorre em solos secos e pedregosos de encostas de morro; associada a formações campestres herbáceas, subarbustivas ou arbustivas (vassourais); campos rupestres.

Observações: floresce e frutifica da primavera a meados do outono, com picos em outubro/ novembro e março/ abril. A espécie é considerada, segundo critérios da IUCN, como "quase ameaçada" (NT), pois apresenta extensão de ocorrência relativamente pequena, porém as populações não são muito pequenas e o grau de fragmentação não é elevado.

P. curticeps, até então considerada sinônimo de Porophyllum lanceolatum DC., está sendo revalidada em função das diferenças observadas entre esses dois táxons. No protólogo de $P$. curticeps são indicados diferentes exemplares e a busca pelos tipos nomenclaturais revelou a existência de cinco exsicatas com igual status, o que levou à lectotipificação de P. curticeps (Carneiro \& Ritter 2016). Percebeu-se que havia uma confusão na identificação entre essas duas espécies nas exsicatas de herbário: o epíteto "curticeps", utilizado por Malme em referência ao comprimento das brácteas involucrais, foi interpretado como uma referência ao tamanho dos espécimes, o que fez com que muitos exemplares de pequeno porte de $P$. lanceolatum fossem identificados como $P$. curticeps, uma vez que são espécies afins. As principais diferenças entre essas espécies são a cor das flores (amarelo-claras em P. lanceolatum) e brácteas involucrais (esverdeadas e não vináceas em $P$. lanceolatum), o comprimento dos pedúnculos (mais longos em P. lanceolatum) e o número de capítulos ( $P$. curticeps tem frequentemente três ou quatro capítulos por ramo da sinflorescência, raramente capítulos isolados, enquanto $P$. lanceolatum tem geralmente um ou dois, raramente três), além do porte (maior em P. curticeps, chegando a ultrapassar $1 \mathrm{~m}$ de atura).

P. curticeps apresenta grande variação morfológica no aspecto vegetativo: ereta e com folhas estreitas e membranáceas em solos rochosos de encosta de morro ou ascendente a ereta, mais ramosa e com folhas crassiúsculas mais largas nos espécimes do litoral.

Material selecionado: BRASIL, RIO GRANDE DO SUL, Capão da Canoa, próximo ao Morro Alto, 4.X.2003, V.F. Kinupp \& J.A .Jarenkow 2765 (ICN); Porto Alegre, Morro São Pedro, Econsciência Espaço de Conservação, 10.XI.2005, R. Setubal \& J. Bassi 218 (ICN); São Francisco de Paula, Floresta Nacional (FLONA-SPF), Morro dos Cavalos, 11.VI.2008, G.D.S. Seger 636 (ICN); Torres, Parque Estadual de Itapeva, 12.III.2013, C.R. Carneiro 53 (ICN); Viamão, Parque Estadual de Itapuã, $30^{\circ} 21^{\prime} 34,20^{\prime \prime}$, $51^{\circ} 01^{\prime} 45,00$ 'W, trilha da Pedra da Visão, 20.III.2013, C.R. Carneiro 59 (ICN). SANTA CATARINA, Araranguá, Morro dos Conventos, 28 $56^{\prime} 21,6^{\prime \prime} \mathrm{S}, 49^{\circ} 21^{\prime} 46,5^{\prime \prime} \mathrm{W}$,
07.IX.2012, C.R. Carneiro 05 (ICN); Florianópolis, Lagoa Pequena, 20.XI.2010, T.B. Guimarães $s / n^{\circ}$ (ICN 169295); Garopaba, Praia do Ferrugem, 12.X.1989, $H$. Janke 06 (HAS); Içara, 2848'18,00"S, 49¹3'05,00”O, Balneário Rincão, 9.XII.2010, A. Korte \& M.J. Rigon Jr. 5527 (FURB); Imbituba, Nova Esperança, 8.X.1977, G. Hatschbach \& E. Forero 40372 (MBM); Laguna, 16.X.1971, G. Hatschbach \& C. Koczicki 27239 (MBM); Palhoça, Campo do Maciambu, 18.XII.1952, P.R. Reitz 4844 (HBR); Sombrio, próximo a Araranguá, 19.X.1944, P.R. Reitz C 800 (HBR).

2.3 Porophyllum lanceolatum DC., Prodr. 5: 649. 1836. (Figs. 2 H-N; Fig. 6 D)

Subarbustos perenes, eretos, $10-80 \mathrm{~cm}$ alt., rizomatosos ou xilopodíferos, ginodioicos, ramos cilíndricos lenhosos, simples ou pouco ramificados. Folhas alternas ou opostas, pecioladas; pecíolos 1,5-3 mm, lâminas 15,5-49 x 2,6-7,8 $\mathrm{mm}$, lanceoladas ou estreito-elípticas, membranáceas, verde-oliva ou glaucas, ápice foliar obtuso, obtusomucronado ou agudo, base atenuada, margem inteira ou crenada, glabras, uninervadas, nervura central evidente, glândulas 1-2,8 mm compr., lineares, dispostas ao longo da margem. Capítulos isolados terminais ou em sinflorescências corimbiformes laxas de 2 ou mais raramente 3 capítulos por ramo. Capítulos com 15-35 flores; pedúnculos 6-28 (35) mm compr., pouco engrossados no ápice. Invólucro cilíndrico, 5 brácteas livres, 10,2-14,2 x 2,1-2,9 mm, lineares ou linear-oblongas, ápice triangular ou agudo, planas ou levemente curvadas, glabras, verdes a levemente vináceas, bordas hialinas, glândulas menores do que a metade do comprimento da bráctea. Receptáculo 1,4$1,8 \mathrm{~mm}$ diâm., plano, alveolado. Flores monoclinas com corola 7,8-8,4 x 1,8 mm na porção mais larga, amareloclara, tubo da corola estreito, ápice dilatado, lobos ca. 1,8 x 0,8 mm, agudos. Anteras 2,2 mm compr., amarelas ou amarelo-pálidas, apêndices basais sagitados. Estilete ca. $8,5 \mathrm{~mm}$ compr., ramos 2-2,2 $\mathrm{mm}$ compr. Flores pistiladas com corola 6,3-7,2 x 0,85-0,95 mm na porção mais larga, amarelo-clara, tubo da corola estreito, ápice dilatado, lobos ca. 1,2 x 0,5 mm., agudos. Estaminódios 5, 1,1-1,2 mm, filiformes, ápice lanceolado, inclusos. Estilete 7,3-8,5 $\mathrm{mm}$ compr., ramos ca. $2 \mathrm{~mm}$ compr. Cipselas 5,1-8,2 mm compr., marrom-escuras, hispidulosas, tricomas claros a amarelo-dourados; carpopódio 0,35-4 mm compr. Pápus 6,9-8,3 mm compr., unisseriado, cerdas amarelo-claras ou amarelo-claro douradas, barbeladas.

Distribuição geográfica: no Brasil, a espécie ocorre no Rio Grande do Sul, com distribuição ampla, porém fragmentada. É citada também para a Argentina e o Paraguai (Zuloaga et al. 2014).

Habitat: campos com solos secos e pedregosos, com vegetação herbácea ou subarbustiva, conforme observações de campo.

Observações: floresce e frutifica de outubro a janeiro. 
Conforme os critérios da IUCN, a espécie classifica-se como "em perigo" (EN), sob o critério B2ab(iii), pois apesar da ampla extensão de ocorrência, os indivíduos ocorrem isoladamente ou formando populações muito pequenas e as áreas de ocorrência são muito restritas e extremamente fragmentadas.

Trata-se de uma espécie de identidade um tanto confusa, havendo espécimes com morfologia muito variada identificados sob o nome $P$. lanceolatum, o que torna difícil sua circunscrição. Jonhson (1969) sinonimizou grande número de espécies com morfologia muito discrepante sob P. lanceolatum, contribuindo nesse sentido. A própria descrição da espécie em floras regionais (Cabrera 1974, Petenatti \& Ariza-Espinar 1997) muitas vezes não coincide com a descrição original e com os materiais-tipo. No presente trabalho, a circunscrição da espécie encontra-se mais restrita, considerando diversos materiais encontrados para a área de estudo (estado do Rio Grande do Sul), bem como materiais da Argentina e Paraguai vistos por meio de imagens. Excluíram-se alguns materiais analisados através de imagens ou exsicatas, procedentes da Argentina ou do Brasil "extra área de estudo", que parecem tratar-se de outros táxons. Alguns exemplares pertencentes a outras espécies podem apresentar folhas lanceoladas, como é o caso de $P$. ruderale subsp. ruderale (que normalmente tem folhas elípticas) e acabam sendo identificados como $P$. lanceolatum, o que resulta nessa confusão taxonômica. Petenatti \& Ariza-Espinar (1997), por exemplo, descrevem a espécie como "erva anual", o que não condiz com a descrição original ou com o typus. As características principais utilizadas para a circunscrição do táxon foram a presença de folhas lanceoladas ou com formato aproximado, o menor número de capítulos e o porte menor, em relação à P. curticeps, e as flores amarelas, quando possível observar.

Material selecionado: BRASIL, RIO GRANDE DO SUL, Arroio dos Ratos, Granja Faxinal, 24.10.1977, K. Hagelund $s / n^{\circ}$ (ICN 60140); ibidem, -30,26311, -51,72178, 10 out. 2013, C.R. Carneiro 68 (ICN); Giruá, Mato Grande, 1.VI.1976, K. Hagelund $s / n^{\circ}$ (ICN 60142); Guaíba, Fazenda São Maximiano, BR116, km 307, 18.10.1986, N. I. Matzenbacher $s / n^{\circ}$ (ICN 67362); Herval, estrada Herval para Pedras Altas, 09.11.2009, E. Barbosa et al. 2472 (MBM); Lavras do Sul, 21.10.2007, A.C. Fernandes $s / n^{\circ}$ (ICN 159184); Pinheiro Machado, $31^{\circ} 37^{\prime} 06,5^{\prime \prime} S$, $53^{\circ} 15^{\prime}$ 06,5”'W, 21.01.2013, C.R. Carneiro 44 (ICN); Santa Rosa, $20 \mathrm{~km}$ SE da cidade, 2.XI.1971, J.C. Lindeman et al. $s / n^{o}$ (ICN 9009); Santiago, 15.I.2013, C.V. Ely $s / n^{o}$ (ICN 192033); São Borja, 57 km SE da cidade, estrada para Santiago, 20.XI.1972, J.C. Lindeman et al. $s / n^{\circ}$ (ICN 021116); Vacaria, Fazenda Ronda, 6.I.1947, B. Rambo SJ 34918 (PACA); Viamão, Campo do Varejão, próximo à Itapuã, 10.IV.1948, K. Emrich s/n ${ }^{\circ}$ (PACA 37455).

2.4 Porophyllum linifolium (Ard.) DC., Prodr. 5: 649. 1836, non Porophyllum linifolium (L.) DC.

(Figs. 3 A-F; Fig. 6 E)
Subarbustos perenes, eretos ou ascendentes, 8-25 $\mathrm{cm}$ alt., xilopodíferos, ginodioicos, ramosos na porção inferior. Folhas alternas ou opostas, inseridas basalmente nos ramos, sésseis; lâminas 9,6-20 x 0,4-1,9 mm, filiformes a estreitamente oblanceoladas, crassiúsculas, confertas, glaucas ou verde-escuras, ápice arredondado, base atenuada, margem inteira, glabras, pelo menos uma glândula linear próxima à extremidade distal da folha, 0,9-1,3 mm compr. Capítulos solitários, 10-35 flores; pedúnculos 4,3-11,2 cm compr., pouco engrossados no ápice. Invólucro cilíndrico, 5 brácteas livres, 6,5-11 x 1,8$3,7 \mathrm{~mm}$, oblongas, ápice obtuso-mucronado, levemente curvadas, glabras, esverdeado-vináceas a intensamente vináceas, às vezes pruinosas na face externa, crassas, bordas hialinas com glândulas menores do que a metade do comprimento da bráctea. Receptáculo 1-1,5 mm diâm., levemente convexo, alveolado. Flores monoclinas, corola 5,8-6,2 x 1-1,2 mm, tubuloso-infundibuliforme, vináceas, tubo da corola estreito na base, gradualmente dilatado em direção ao ápice, lobos $0,6-0,8 \times$ ca. $0,5 \mathrm{~mm}$, agudos. Anteras 1,8-2 mm compr., vináceas ou rosadas, apêndices basais sagitados. Estilete 7,7-9,2 mm compr., ramos 1,4-2,2 $\mathrm{mm}$ compr. Flores pistiladas com corola , 3,5-5,8 x 0,6-0,7 $\mathrm{mm}$ na porção mais larga, tubuloso-filiforme, vináceas; tubo da corola estreito até a metade, alargando-se discretamente a partir desse ponto, lobos 0,4-0,6 x 0,3-0,4 mm, agudos. Estaminódios ausentes ou reduzidos (5), 0,3-0,85 mm, lanceolados ou filiformes com ápice lanceolado, inclusos. Estilete 5,5-7 mm compr., ramos ca. 1,4 mm compr., extremidade obtusa ou arredondada. Cipselas 3,3-4,7 mm compr., marrom-claras a marrom-escuras, hispidulosas, tricomas claros a amarelo-dourados; carpopódio ca. 3,5 $\mathrm{m}$. Pápus 3,2-4,7 mm, unisseriado, cerdas amarelo-clarodouradas, frequentemente manchas vináceas, barbeladas.

Distribuição geográfica: no Brasil, ocorre apenas no Rio Grande do Sul, nas regiões fisiográficas da Campanha, Depressão Central, Encosta do Sudeste, Missões e Serra do Sudeste. Além disso, ocorre na Argentina, nas províncias de Corrientes, Entre Rios e Misiones, e no Uruguai, onde se distribui por diversos departamentos (Zuloaga et al. 2014). Habitat: formações campestres, em locais com solos secos ou pouco úmidos e vegetação herbácea, em baixas altitudes. Observações: a floração e a frutificação ocorrem de outubro a janeiro.

Conforme critérios da IUCN a espécie classifica-se como "em perigo" (EN), sob o critério B2ab(iii), pois apesar da extensão de ocorrência ser relativamente ampla, as populações são muito pequenas e fragmentadas, além de sujeitas ao declínio da qualidade do habitat devido à pecuária, agricultura e construção de estradas.

Material selecionado: BRASIL, RIO GRANDE DO SUL, Alegrete, $29^{\circ} 37^{\prime} 18,4^{\prime \prime}$ 'S, $56^{\circ} 16$ '36,4'W, estrada de chão de Itaqui para Alegrete, 24.I.2013, C.R. Carneiro 49 (ICN); Arroio dos Ratos, Fazenda Faxinal, 24.X.1977, K. Hagelund 11961 (ICN); Caçapava do Sul, 30S 33'11", 


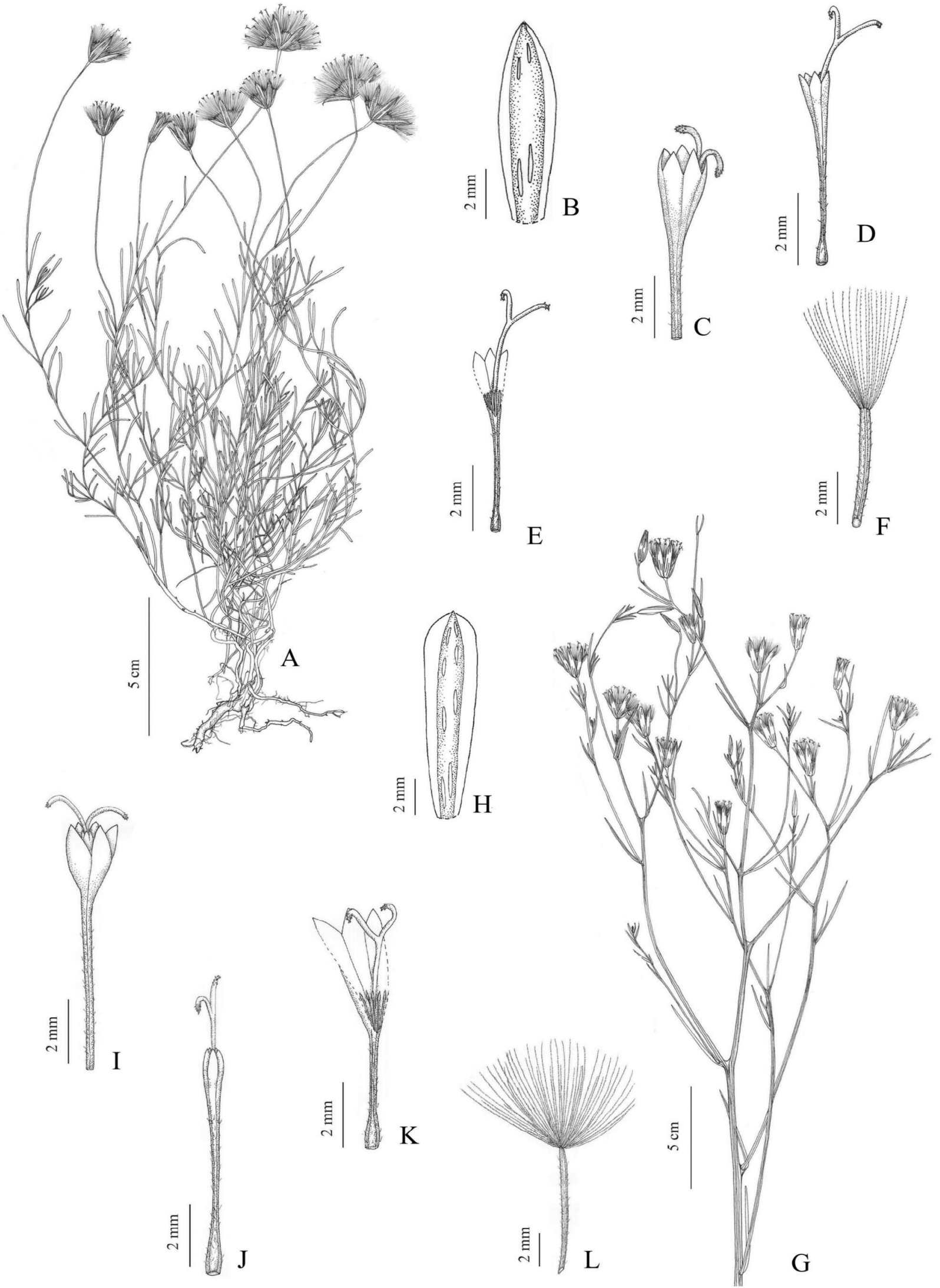

Figs. 3. A-L. A-F. Porophyllum linifolium (Ard.) DC. A. Hábito; B. Bráctea involucral; C. Flor monoclina; D. Flor pistilada; E. Flor pistilada aberta mostrando os estaminódios; F. Cipsela e pápus (A. C.R. Carneiro 50, ICN; B, C. C.R. Carneiro 32 ICN; D, E, F. A.A. Schneider 1561, ICN). G-L. Porophyllum obscurum (Spreng.) DC. G. Detalhe do ramo; H. Bráctea involucral; I. Flor monoclina; J. Flor pistilada; K. Flor pistilada aberta mostrando os estaminódios; L. Cipsela e pápus. (G. G. Hatschbach \& P. Ravena 23057, MBM; H, I, L. K. Hagelund 7857, ICN; J. K. Hagelund 7864, ICN; K. E. Pasini 887, ICN). 
53W 26' 42", 30.X.1999, R. Wasun 211 (MBM); Candiota, 21.10.2007, A.C. Fernandes $s / h^{o}$ (ICN 159188); Herval, Serra do Herval, próximo a Pinheiro Machado, 1.XI.1961, Sacco et al. 1544 (HB, PEL; Itacurubi, 2848'36,05'S, $55^{\circ} 04^{\prime} 22,71^{\prime \prime} \mathrm{W}, 8 . X I I .2012$, C.R. Carneiro 32 (ICN); Jaguarão, 2.XI.1961, Sacco et al. 1548 (HB, PEL); Pinheiro Machado, 20.XI.1984, W. Foustrenter $s / n^{\circ}$ (ICN 69961); Porto Alegre, 30S 08' 10", 51W 11'23,5”, Morro Tapera, 9.V.2013, C. Vogel-Ely et al. 97 (ICN); Quaraí, 7.XI.2007, A.A. Schneider 1561 (ICN); Santana do Livramento, Cerro do Registro, João Duarte, 11.XI.2009, E. Barbosa et al. 2512 (MBM); São Gabriel, 30³5'14”S, 540 07'5,8”'W, estrada de chão para Lavras do Sul, 25.I.2013, C.R. Carneiro 50 (ICN). URUGUAI, MONTEVIDEO, Montevideo, barra do Rio Santa Luzia, 1951, J. Mattos 262 (HAS).

2.5 Porophyllum obscurum (Spreng.) DC., Prodr. 5: 651. 1836.

$$
\text { (Figs. } 3 \text { G-L; Fig. } 6 \text { F) }
$$

Ervas ou subarbustos perenes, eretos, 0,3-1 m alt., xilopodíferos, ginodioicos, caule cilíndrico, estriado, não ramificado ou pouco ramificado na base, ramificado na porção superior. Folhas alternas, sésseis; lâminas 11-20 x 0,65-1,1 mm, lineares, às vezes linear-lanceoladas, $42-73 \mathrm{x}$ 1,4-3,5 mm, membranáceas a crassiúsculas; lâminas lineares com ápice agudo a arredondado, base atenuada, margem inteira; lâminas linear-lanceoladas com ápice agudo, base atenuada, margem crenada; glabras, uninervadas, glândulas 0,8-2 mm compr., lineares, dispostas ao longo da margem. Capítulos em sinflorescências terminais corimbiformes de 2-6 capítulos por ramo. Capítulos ca. 20 flores; pedúnculos 1,4-11,7 (16-26) mm compr., pouco engrossados no ápice. Invólucro cilíndrico, 5 brácteas livres, 9,7-13,3 (15,8) x 1,6$2,7(3,4) \mathrm{mm}$, lineares ou linear-oblongas, ápice triangular ou agudo, planas ou levemente curvadas, glabras, bordas hialinas com glândulas às vezes maiores que a metade do comprimento da bráctea. Receptáculo 0,85-1,4 mm diâm., plano ou levemente convexo, alveolado. Flores monoclinas, corola 7,4-8 x 0,85-1 mm larg., amarelo-amarronzada; tubo da corola estreito, ápice dilatado, lobos 1-1,1 x 0,5-0,6 mm, agudos. Anteras ca. 2,6 mm compr., amarelo-amarronzadas, apêndices basais sagitados. Estilete 8,5-9,8 mm compr., ramos ca. 2,5 mm compr. Flores pistiladas com corola 7,3-8,7 mm x 0,6-0,9 mm, tubulosa-filiforme, amareloclara; tubo da corola estreito, lobos 0,5-1,5 x 0,3-0,4 mm, agudos. Estaminódios 5, 1,5-2 mm compr., filiformes, ápice lanceolado, inclusos. Estilete 10,6-11,2 mm compr., ramos 1,4-2,8 mm compr. Cipselas (5,6) 7,1-8,3 mm compr., marrom claras a negras, hispidulosas, tricomas claros a ferrugíneos; carpopódio ca. 0,2 mm compr., claro. Pápus 5,7-8,8 mm compr., unisseriado, cerdas amarelo-clarodouradas a avermelhado-escuras, barbeladas.

Distribuição geográfica: no Brasil essa espécie ocorre na Bahia, Distrito Federal, Goiás, Mato Grosso, Mato Grosso do Sul, Minas Gerais, Paraná (na região de campos ao sul), Rio Grande do Sul (região das Missões) e São Paulo (Carneiro 2018), sendo também citada na mesma referência para Santa Catarina, porém não foram encontrados exemplares em campo ou em herbários que confirmem a ocorrência neste estado. Além disso, a espécie é citada para a Argentina, Paraguai e Uruguai (Zuloaga et al. 2014). Habitat: conforme informações de etiquetas de herbário, essa espécie ocorre em formações campestres, em solos secos e pedregosos (campos rupestres) com vegetação herbácea, subarbustiva ou arbustiva.

Observações: na área de estudo, a espécie floresce e frutifica de novembro a abril. Apesar da ampla extensão de ocorrência, a espécie apresenta baixa área de ocupação, sendo altamente fragmentada. $\mathrm{O}$ baixo número de coletas (principalmente recentes) e o fato de não ter sido encontrado durante o estudo, indicam que o táxon é de ocorrência rara e sensível às alterações no habitat, formando populações pequenas e em provável declínio no número de indivíduos. Diante disso, a classificação segundo os critérios da IUCN é "em perigo" (EN), sob o critério B2ab(iii), pois, sobretudo no caso do Rio Grande do Sul, a região de ocorrência está profundamente afetada pela atividade agrícola, principalmente a monocultura da soja.

Petenatti \& Ariza-Espinar (1997) chamaram atenção para o fato de $P$. obscurum ser uma "espécie polimorfa", opinião compartilhada por Cabrera (1974) ao referir-se à espécie como "de sistemática muito confusa". Esse fato foi constatado nesse estudo, uma vez que foi observada uma grande variedade de morfotipos diferentes identificados como P. obscurum. A descrição da espécie (e o próprio typus) refere-se a caule "alto", simples, ramificandose pouco e apenas na parte superior, e folhas lineares. Observou-se que, em geral, os indivíduos apresentam folhas mais esparsamente distribuídas do que $P$. angustissimum, espécie afim. Os espécimes provenientes do Rio Grande do Sul e Paraná analisados apresentam essas características, porém grande número de espécimes argentinos, analisados por meio de imagens, são ramificados desde a base e densamente folhosos, embora as folhas sejam também lineares. Alguns espécimes argentinos identificados como $P$. obscurum parecem tratar-se de $P$. angustissimum, de fato. Outros, com grande variação entre si, não parecem pertencer a nenhuma das duas espécies. Além disso, outros exemplares coletados no Rio Grande do Sul (também na região das Missões) enquadram-se nessa problemática e requerem um estudo mais aprofundado, não tendo sido considerados na descrição e material examinado.

Material selecionado: ARGENTINA, CORDOBA, Sierra de Pocho, 1.II.1974, A.L. Cabrera et al. 24813 (MBM). CORRIENTES, Empedrado, 6.XII.1977, T.M. Pedersen s/ $n^{\circ}$ (ICN 45552). SALTA, Quebrada de Las Conchas, Tres Cuscos, 3.III.1971, A.L. Cabrera et al. 21796 (MBM). SANTIAGO DEL ESTERO, Guasayán, Serra de Guasayán, road from Santa Catalina to Lavalle, 25.V.1980, T.M. Petersen 12830 (MBM). BRASIL, BAHIA, Barra da Estiva, $13^{\circ} 35^{\prime} \mathrm{S}, 41^{\circ} 18^{\prime} \mathrm{W}$, Chapada Diamantina, Morro do Ouro, 25.IX.2010, M.L. Guedes et al. 17655 (MBM). DISTRITO 
FEDERAL, Brasília, Catetinho, 12.IV.1963, E. Santos \& J. Sacco 1665 (PEL). GOIÁS, São João da Aliança, Rodovia GO012, 23.V.1975, G. Hatschbach 36718 (MBM). MINAS GERAIS, Grão Mogol, 16S 33'39”, 42W 52' 32”, estrada para Virgem da Lapa, ca. 2 km de Grão Mogol, próximo à antena de televisão, 13.VII.2001, V.C. Souza et al. 25842 (ESA, ICN). PARANÁ, Mandirituba, Rod. BR116, próximo do posto da Polícia Rodoviária Federal, 27.I.2004, J.M. Silva et al. 3957 (MBM); Palmeira, Rio Tibagi, 21.II.1981, G. Hatschbach 43640 (MBM); Ponta Grossa, Rio Guavirova, 3.XII.1969, G. Hatschbach \& P. Ravena 23057 (HB, MBM). RIO GRANDE DO SUL, Entre-Ijuís, entre São João Mirim e Carajazinho, 27.I.1964, E. Pereira \& G. Pabst 8644 (HB, PEL); Manuel Viana, S29 39.659 W55 23.655, Cerro do Tigre, 23.IV.2011, E. Pasini 887 (ICN); Santo Ângelo, Granja Piratini, 8.XII.1973, K. Hagelund 7857 (ICN).

2.6 Porophyllum ruderale (Jacq.) Cass., Dict. Sci. Nat., ed. 2. [F. Cuvier] 43: 56. 1826. Porophyllum ruderale (Jacq.) Cass. subsp. ruderale

$$
\text { (Figs. } 4 \text { A-E; Fig. } 6 \text { G) }
$$

Ervas anuais eretas, 0,5-1,5 m alt., homoicas, raiz pivotante, caule cilíndrico, estriado, glabro, esverdeado ou marrom, bastante ramificado na porção superior. Folhas alternas ou opostas, pecioladas; pecíolos 5,6-17 $(28,5)$ mm compr., lâminas 22-58 (90) x 7-22 (31) mm, elípticas, estreito-elípticas ou obovaladas, membranáceas, glaucas, ápice foliar obtuso, acuminado ou mucronado, base cuneada, margem crenada ou sinuada, glabras, peninérvias, glândulas 1-2 mm compr., lineares, dispostas ao longo da margem, junto às reentrâncias, às vezes também dispe rsas pelo limbo. Capítulos solitários ou dispostos em sinflorescências corimbiformes terminais de 2-6 capítulos por ramo. Capítulos com 47-56 flores; pedúnculo 11-30 (62) mm compr., pouco engrossado no ápice. Invólucro cilíndrico, 5 brácteas livres, 17-21 x 2-3 mm, linear-acuminadas, planas, glabras, esverdeadas ou vináceas, bordas hialinas com glândulas às vezes maiores do que a metade do comprimento da bráctea. Receptáculo 2-2,8 mm diâm., plano, alveolado. Flores isomorfas, monoclinas, corola 11-14 mm x 0,9-1,05 $\mathrm{mm}$ na porção mais larga, amarelo-esverdeada ou arroxeada; tubo da corola longo e estreito, ápice abruptamente dilatado, lobos ca. 1 x 0,4 mm. Anteras rosadas, 1,3-1,5 mm compr., apêndices basais sagitados. Estilete 12,2-14,7 mm compr., ramos 2,1-3,2 mm compr., fortemente recurvados. Cipselas 7-8 mm compr., marrom-escuras ou negras, puberulentas, tricomas esbranquiçados; carpopódio ca. 0,35 mm. Pápus 9-10,6 mm compr., unisseriado, cerdas branco-amareladas, discretamente barbeladas.

Distribuição geográfica: a espécie é amplamente distribuída, do sudoeste dos Estados Unidos ao norte da Argentina. P. ruderale subsp. ruderale, é mais amplamente distribuída, sendo predominantemente tropical, estendendose da Costa Rica ao norte da Argentina, em altitudes geralmente inferiores a $1.300 \mathrm{~m}$ (Johnson 1969). No Brasil, ocorre em todas as regiões. Já a outra subespécie, P. ruderale subsp. macrocephalum (DC.) R.R. Johnson, tem distribuição mais ao norte, ocorrendo do extremo sudoeste dos Estados Unidos ao norte do Brasil, sul do Peru e Bolívia, preferencialmente em áreas não perturbadas e em grandes altitudes (Johnson 1969).

Habitat: planta ruderal, comum em locais alterados e antropizados como beira de estradas, lavouras e terrenos baldios (conforme observações de campo, etiquetas de exsicatas e também Lorenzi 2000).

Observações: floresce e frutifica o ano todo, mais comumente de outubro a abril. Fortemente aromática, é utilizada com fins medicinais, sendo popularmente conhecida como "arnica", "couve-cravinho", "picãobranco" e "cravo-de-urubu" e tem uso tópico no tratamento de ferimentos, traumatismos e contusões, e uso sistêmico como estomáquica (Lorenzi \& Matos 2008). É considerada também uma erva-daninha, pelo fato de ocorrer em lavouras, porém não apresenta grande potencial invasor (Lorenzi 2000).

Segundo os critérios da IUCN, insere-se na categoria LC (menos preocupante), por ser uma espécie amplamente distribuída e ruderal, não sendo afetada pela ação antrópica. Nesse trabalho, o reconhecimento de subespécies segue o trabalho de Johnson (1969). P. ruderale subsp. ruderale, caracteriza-se por possuir folhas de até $90 \times 30 \mathrm{~mm}$, normalmente elípticas, brácteas involucrais acuminadas e pedúnculos pouco a moderadamente dilatados. Já Porophyllum ruderale subsp. macrocephalum apresenta folhas de até $3,5 \times 2,5 \mathrm{~cm}$, ovaladas ou obovaladas, brácteas involucrais não acuminadas e pedúnculos fortemente dilatados.

Os exemplares de Porophyllum ruderale subsp. ruderale analisados apresentam morfologia muito variada, característica condizente com a sua condição de táxon amplamente distribuído.

Material selecionado:ARGENTINA, CORRIENTES, Corrientes, Ruta 12 y Ayo. Riachuelo, 4.I.1976, A. Schinini \& R. Martinez Crovetto 12337 (MBM). ENTRE RIOS, Concordia, Parque Rivadavia, 20.II.1981, A.A. Sáenz 137 (MBM). MISIONES, Candelaria, Ruta 4 hacia Santa Ana, $5 \mathrm{~km}$ antes del desvío a Oberá, 18.XII.1986, C.C. Xifreda \& S. Maldonado 554 (MBM). BRASIL, BAHIA, Campo Formoso, 10³2'03”S, 40¹8'23”W, BA-220, riacho Lava Pé, a $5 \mathrm{~km}$ da rótula de Antônio Gonçalves, 20.VIII.1998, H.P. Bautista \& J. Rodriguez-Oubiña 2415 (MBM). CEARÁ, Guaramiranga, 24.VII.1984, $F$. Cavalcante $s / n^{\circ}$ (MBM 101627). GOIÁS, Alto Paraíso de Goiás, margem da rodovia GO354, km 09, 19.VII.2007, L.F. Lima 431 (ICN). MATO GROSSO, Barão de Melgaço, RPPN SESC Pantanal, 2.II.2002, S.R. Zaniolo et al. $s / n^{o}$ (UPCB 50047). MATO GROSSO DO SUL, Aquidauana, Fazenda Cacimba de Pedra, 20.III.2004, G. Hatschbach et al. 77334 (MBM). MINAS GERAIS, Santa Rita do Sapucaí, Timburé, 26.II.2001, O.S. Ribas \& A.M.S. 


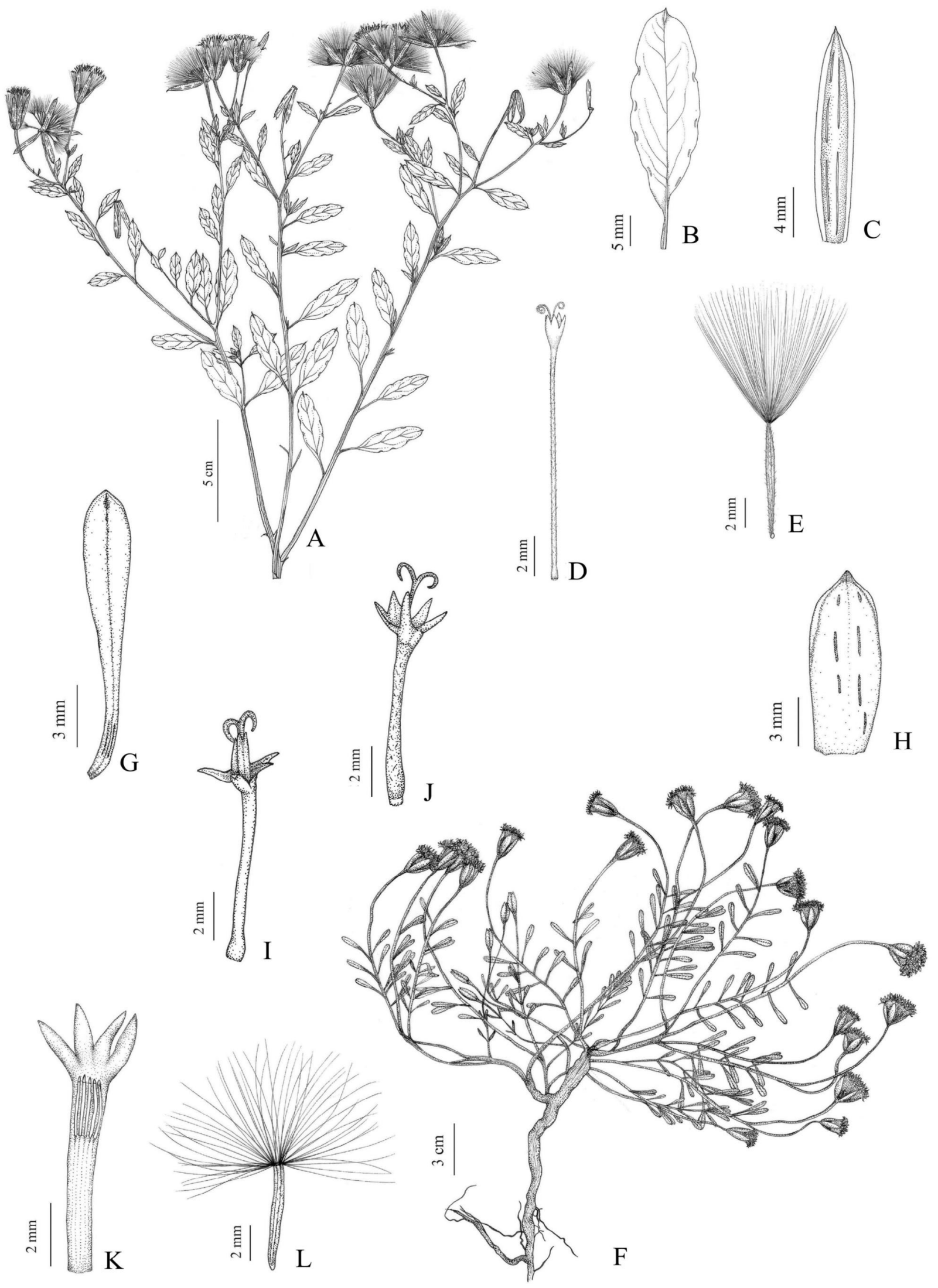

Figs. 4. A-L. A-E. Porophyllum ruderale (Jacq.) Cass. subsp. ruderale. A. Detalhe dos ramos; B. Folha; C. Brátea involucral; D. Flor; E. Cipsela e pápus (A. C.R. Carneiro 28, ICN. B. C.R. Carneiro $s / n^{\circ}$, ICN 169299. C-E. C.R. Carneiro 20, ICN). F-L. Porophyllum spathulatum C.R.Carneiro \& A.A.Schneid. F. Hábito; G. Folha; H. Bráctea involucral; I. Flor monoclina; J. Flor pistilada; K. Flor pistilada aberta (um lobo removido), mostrando os estaminódios; L. Cipsela e pápus (F, G, H, I, L. C.R. Carneiro 73, ICN. J, K. C.R. Carneiro 72, ICN). 
Ponchon 3318 (MBM, UPCB). PARANÁ, Balsa Nova, Ponte dos Arcos, 31.I.2006, C. Kosera \& O.P. Kosera 2926 (MBM, UPCB); Diamante do Norte, 24.VII.2009, M. Whelan 86 (MBM); Jundiaí do Sul, Fazenda Monte Verde, 5.II.2001, J. Carneiro 1055 (MBM); Luiziana, 2431'18,5”S, 52 27'06,9”W, Estação Ecológica Luiziana, 11.III.2010, M.G. Caxambu et al. 3005 (HCF); Maringá, $23^{\circ} 21^{\prime} 15,5^{\prime \prime} \mathrm{S}, 51^{\circ} 49^{\prime} 42,7^{\prime \prime} \mathrm{W}$, distrito de Santa Fé, 16.I.2013, C.R. Carneiro 41 (ICN); Palmeira, Rio Tibagi, 3.II.1999, J.M. Cruz et al. 91 (FURB, MBM); Palotina, IAPAR, 12.II.2005, C.B. Empinotti 13 (HUCS, MBM); Pinhão, Rio Jordão, jusante do Salto do Cachorro, 14.II.1996, F. Galvão \& Y.S. Kuniyoshi 36 (MBM); Pitanga, 2453'45,3'S, 51'40'26,1'W, 17.I.2013, C.R. Carneiro 42 (ICN); Pontal do Paraná, 17.X.1997, S.M. Silva et al. $s / n^{\circ}$ (UPCB 33617). RIO DE JANEIRO, Mangaratiba, Bahia de Sepetiba, Ilha Furtada, 3.XI.1967, D. Sucre 1834 (HB). RIO GRANDE DO SUL, Bagé, 31 $1^{\circ} 12^{\prime} 43,4^{\prime \prime}$ 'S, 54 17'09,3”W, em direção a Dom Pedrito, 22.I.2013, C.R. Carneiro 45 (ICN); Caçapava do Sul, em frente à Pedra do Segredo, 25.III.1985, O. Bueno et al. 4179 (HAS); Candelária, 2942'42,2”S, 52 ${ }^{\circ} 50^{\prime} 35,7^{\prime}$ 'W, Cerro Botucaraí, 25.XI.2012, C.R. Carneiro 18 (ICN); Dom Pedro de Alcântara, 25.VII.1997, S. Dalpiaz \& L.R.M. Baptista $s / n^{\circ}$ (ICN 115256); Erechim, IBDF, 6.IV.1993, A. Butzke et al. $s / n^{\circ}$ (HUCS 10688); Nova Prata, Cascata da Usina, 2.III.1989, M. Poloni et al. $s / n^{\circ}$ (HUCS 5343, MBM 128464); Pantano Grande, Rincão Gaia, 2.II.1993, $J$. Larocca $s / h^{\circ}$ (PACA 92566); Passo Fundo, IV.2009, $M$. Savaris 14 (ICN); Pelotas, Retiro, 10.III.1958, J.C. Sacco 962 (HB, PACA, PEL); Porto Alegre, UFRGS, Instituto de Pesquisas Hidráulicas, 19.IX.2010, C.R. Carneiro $s / n^{\circ}$ (ICN 169299); Santa Maria, Campus UFSM, XII.1992, A.C.F. Matos et al. (SMDB 4629); Santo Ângelo, Granja Piratini, II.1971, K. Hagelund 6132 (ICN); 26.XI.1974, K. Hagelund 8358 (ICN); Santo Antônio das Missões, estrada de chão para Garruchos, 9.XII.2012, C.R. Carneiro 35 (ICN); São

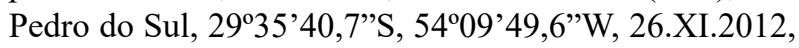
C.R. Carneiro 19 (ICN). SANTA CATARINA, Campos Novos, BR470, ca. $4 \mathrm{~km}$ da ponte sobre o Rio Uruguai, 29.XII.1997, J.A. Jarenkow 3749 (PEL); Concórdia, Volta Grande, próx. ponte ferroviária sobre o Rio Uruguai (M. Ramos), 23.XII.1996, J.A. Jarenkow 3386 (MBM, PEL); Dionísio Cerqueira, 26⒈'06,6”S, 5339'32,9”'W, Linha Jorge Lacerda, 27.XI.2012, C.R. Carneiro 21 (ICN); Florianópolis, Ilha de Santa Catarina, Joaquina, 8.I.1992, M.H. de Queiroz 599 (FLOR); Lindóia do Sul, $27^{\circ} 00^{\prime} 00,00^{\prime} \mathrm{S}, 52^{\circ} 01^{\prime} 12,00^{\prime} \mathrm{O}$, Próximo à rodovia $\mathrm{SC} 488$, na divisa com Irani, 11.IV.2011, A. Korte 6523 (FURB). SÃO PAULO, Santa Rita do Passa Quatro, $47^{\circ} 34-41^{\prime} \mathrm{W}$ e 2136-44'S, Cerrado Pé-de-Gigante, 6.III.1997, M.A. Batalha 1631 (SP). COLOMBIA, MAGDALENA, Bonda, 22.VI.1969, P. Santiago Díaz 186 (MBM). PERU, MAYNAS, Iquitos, Jardim Institute Botanical, 20.XII.1981, M. Rimachi Y. 10134 (MBM); VENEZUELA, YARACUY, Distrito San Felipe, $10^{\circ} 14^{\prime}$ N, 68³6’30'W, 30.XII.2003, W. Meier \& O Escorcha 9735 (MBM).
2.7 Porophyllum spathulatum C.R.Carneiro \& A.A.Schneid. Phytotaxa 173(2): 157. 2014

(Figs. 4 F-L; Fig. 6 H)

Subarbustos perenes, decumbentes, ramos ascendentes, 10-20 cm alt., ginodioicos; raiz pivotante profunda; caule cilíndrico, ramificado, nós evidentes. Folhas alternas ou opostas, pseudopecioladas; pecíolos 2,2-3,6 mm compr., lâminas 14-20 x 2,4-4,2 mm, espatuladas, glaucas, ápice arredondado, base atenuada, margem inteira, glabras, uninervadas, par de glândulas lineares na base, geralmente uma glândula solitária no ápice, às vezes algumas irregularmente dispostas ao longo da margem, 0,4-0,9 $\mathrm{mm}$ compr. Capítulos solitários, 52-66 flores; pedúnculos 28-48 (60) mm compr., engrossados no ápice. Invólucro cilíndrico, 5 brácteas livres, 12,2-16 x 3,7-5,4 mm, oblongas, ápice obtuso-mucronado, pruinosas, glaucas a levemente vináceas, bordas hialinas com glândulas menores do que a metade do comprimento da bráctea. Receptáculo 2,25-4,6 mm diâm., plano, alveolado. Flores monoclinas, corola 7,7-12,3 x 1,3-2 mm larg., amarelo-clara; tubo da corola estreito, ápice dilatado, lobos 1,5-1,7 x 0,5 mm compr., agudos. Anteras 2,6-3 mm compr., exsertas, amarelas, apêndices basais sagitados. Estilete 13,2-14,6 mm compr., ramos 2-2,2 mm compr. Flores pistiladas, corola 8,6-10,7 x 1,3-2 mm, amarelo-clara, tubo da corola estreito, ápice dilatado, lobos ca. 1,7 x 0,6 mm, agudos. Estaminódios 5, ca. $2 \mathrm{~mm}$ compr., filiformes com ápice lanceolado, inclusos. Estilete 10,7-11,2 mm, ramos 1,6-2 mm. Cipselas 6,3-9,3 $\mathrm{mm}$ compr., marrom-escuras, puberulentas a glabrescentes, tricomas amarelados; carpopódio 0,3-0,45 mm compr. Pápus 8-9,5 mm compr., unisseriado, cerdas amareloclaras, barbeladas.

Distribuição geográfica: endêmica da Praia do Hermenegildo, no município de Santa Vitória do Palmar, Rio Grande do Sul.

Habitat: solos arenosos, em dunas secundárias ou em baixada seca entre dunas.

Observações: a espécie floresce e frutifica de novembro a fevereiro. Classifica-se, segundo critérios do IUCN, como criticamente em perigo (CR), sob os critérios B1ab(iii) + 2ab(iii), D), pois é encontrada em apenas um local, com uma pequena população de 21 indivíduos. Além disso, a espécie está sujeita ao declínio na qualidade do habitat, uma vez que o local de ocorrência sofre intensa ação antrópica no verão, havendo cada vez mais construções e despejo de lixo e esgoto. Soma-se a isso a presença de espécies exóticas agressivas no local.

Assemelha-se à Porophyllum brevifolium (Hook. \& Arn.) Malme, uma espécie endêmica de substrato rochoso do litoral do Uruguai, pelo fato de ambas possuírem folhas espatuladas e hábito decumbente. Entretanto, as mesmas diferem em várias características: P. brevifolium tem porte e capítulos menores (o diâmetro do receptáculo é de ca. $1.6 \mathrm{~mm}$ e o comprimento das brácteas involucrais é de 
12-12.5 mm, enquanto em $P$. spathulatum essas estruturas medem respectivamente $2.25-4.6 \mathrm{~mm}$ e $2.25-4.6 \mathrm{~mm}$ ), flores intensamente vináceas, folhas menores $(6.4-12.3 \mathrm{~mm}$ compr. x 1.5-2 larg., contra $14-20 \mathrm{~mm}$ compr. x 2.4-4.2 mm larg. em P. spathulatum), crassas e mais densamente dispostas (confertas). Malme (1899) cita a ocorrência de P. brevifolium para o Rio Grande do Sul, na localidade de Senandes, em Rio Grande, município vizinho a Santa Vitória do Palmar. Porém, pela descrição apresentada, é provável que estivesse referindo-se à $P$. spathulatum.

Material examinado: BRASIL, RIO GRANDE DO SUL, Santa Vitória do Palmar, Hermenegildo, $17 \mathrm{~km}$ ao norte do Chuí, II.1978, Pfadenhauer 671 (ICN); ibidem, XII.1987, C. Costa $s / n^{\circ}$ (ICN 86371); ibidem, $33^{\circ} 39^{\prime} 26,2^{\prime \prime} \mathrm{S}, 53^{\circ}$ 14' 50,2" W, 3.V.2013, C.R. Carneiro 62 (ICN); ibidem, $33^{\circ} 40^{\prime} 21^{\prime \prime} \mathrm{S}, 53^{\circ} 16^{\prime} 11^{\prime}$ 'W, 16.XI.2013, C.R. Carneiro 72 (ICN).

\section{Tagetes L., Sp. Pl. 2: 887. 1753.}

Ervas, subarbustos ou arbustos, anuais ou perenes, glabros ou glabrescentes. Folhas opostas, geralmente pinatissectas, às vezes inteiras, contorno linear a lanceolado, glândulas dispersas pelo limbo. Capítulos normalmente radiados, pedunculados, terminais, solitários ou em cimeiras paniculiformes ou corimbiformes, laxas ou congestas. Invólucro cilíndrico, fusiforme ou campanulado; brácteas involucrais 3-10, uma série, fusionadas exceto pelo ápice, duas fileiras longitudinais de glândulas alongadas ou puntiformes. Receptáculo plano ou cônico, alveolado. Flores do raio geralmente presentes, unisseriadas, limbo geralmente amarelo ou laranja, raramente branco, ápice bilobado ou trilobado. Flores do disco monoclinas, corola tubulosa, cilíndrica, pentalobada, lobos triangulares ou lanceolados. Antera com base obtusa ou arredondada, apêndice do conetivo lanceolado ou ovalado. Ramos do estilete com ápice agudo, deltado ou truncado, papiloso. Cipselas fusiformes, às vezes comprimidas, escuras, glabras ou com tricomas curtos. Pápus com 3-10 páleas, tamanhos desiguais, uma ou algumas longas e aristiformes, as demais curtas e escamiformes.

Gênero com cerca de 45 espécies, nativo da América tropical e subtropical, distribuindo-se do sul dos Estados Unidos e México até o norte da Patagônia na Argentina (Petenatti \& Ariza-Espinar 1997),

Na área de estudo ocorrem duas espécies nativas: Tagetes minuta L., espécie ruderal de ampla distribuição na América do Sul, e Tagetes osteni Hicken, recentemente citada para o Brasil e anteriormente considerada endêmica do Uruguai. Existem ainda duas espécies exóticas cultivadas, Tagetes erecta L. e Tagetes patula L., popularmente conhecidas como "cravo-de-defunto".
Chave de identificação para as espécies do gênero Tagetes ocorrentes na Região Sul do Brasil

1. Capítulos com flores liguliformes vistosas, lígulas de

5- $20 \mathrm{~mm}$ compr. .............................................................. 2

1'. Capítulos com flores liguliformes pequenas, até ca.

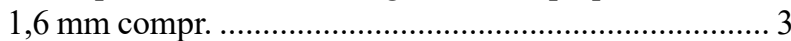

2. Pedúnculo fistuloso, alargado sob o capítulo, invólucro 14-20 x 7- $12 \mathrm{~mm}$, lígula 10- $20 \mathrm{~mm}$ compr.

Tagetes erecta*

2'Pedúnculo fracamente fistuloso ou alargado, invólucro ca. 12 × 6- $7 \mathrm{~mm}$, lígula 5- $8 \mathrm{~mm}$ compr.

Tagetes patula*

3. Flores do disco 8-12, capítulos em sinflorescências de 3-10 capítulos 3.2 Tagetes osteni

3'. Flores do disco 4-6, capítulos em sinflorescências geralmente com mais de 10 capítulos

3.1 Tagetes minuta

* espécies exóticas cultivadas

3.1 Tagetes minuta L., Sp. Pl. 2: 887. 1753. (Figs. 5 A-E; Fig. 6 I)

Ervas anuais eretas, 0,4-2 $\mathrm{m}$ alt., ginomonoicas, raiz pivotante, muito ramificada; caule cilíndrico, estriado, ramificado, esverdeado a amarronzado. Folhas simples, sésseis; lâminas 4,5-13,5 x 3-8 cm, profundamente imparipinatissectas, contorno elíptico, base decurrente, ápice agudo, margem serreada, verde-escuras, glabras ou glabrescentes, peninérvias, glândulas oleíferas translúcidas pontuado-alongadas por toda a margem; 4-8 jugadas, segmentos 20-58 x 1,9-10 mm, lanceolados. Sinflorescências corimbiformes densas, terminais ou axilares, normalmente com mais de 10 capítulos. Capítulos radiados heterógamos, pedúnculos 2,2-5,2 mm compr., não engrossados no ápice; invólucro 8,6-13 x 1,5-2,2 (3) mm, cilíndrico, 3-4 brácteas involucrais, ápice obtuso, glabras ou glabrescentes, verde-amareladas; receptáculo $0,5 \mathrm{~mm}$ diâm, plano. Flores do raio 2-3, corola 3-5,2 mm compr., tubo marrom coberto de tricomas; limbo 0,85-1,6 x 2,3 $\mathrm{mm}$, de cor creme, glabro, bi ou trilobado, lobos desiguais. Estilete 2,7-3,2 mm compr., ramos 0,6-0,7 mm compr., retos ou pouco recurvados, extremidade obtusa. Flores do disco 4-6, 2,3-3,7 x ca. $1 \mathrm{~mm}$, amarelo-amarronzadas, tubo coberto de tricomas, lobos ca. $0,8 \times 0,3 \mathrm{~mm}$, iguais. Anteras 0,95-1,2 mm compr., amarelo-amarronzadas, apêndice do conetivo obtuso, apêndice basal arredondado. Estilete 2-2,4 mm compr., ramos 0,7-0,9 mm compr. Cipselas 5,3-7 $\mathrm{mm}$ compr., fusiformes, comprimidas, marrom-escuras ou negras, hispidulosas, às vezes glabrescentes; carpopódio ca. $0,3 \mathrm{~mm}$., evidente. Pápus com 1 (raramente 2) arista longa, 2-2,7 mm compr., 3 ou 4 aristas escamiformes menores, 0,5-0,9 mm compr.

Distribuição geográfica: no Brasil, a espécie ocorre nas regiões Sul, Sudeste, Centro-Oeste e parte das regiões 


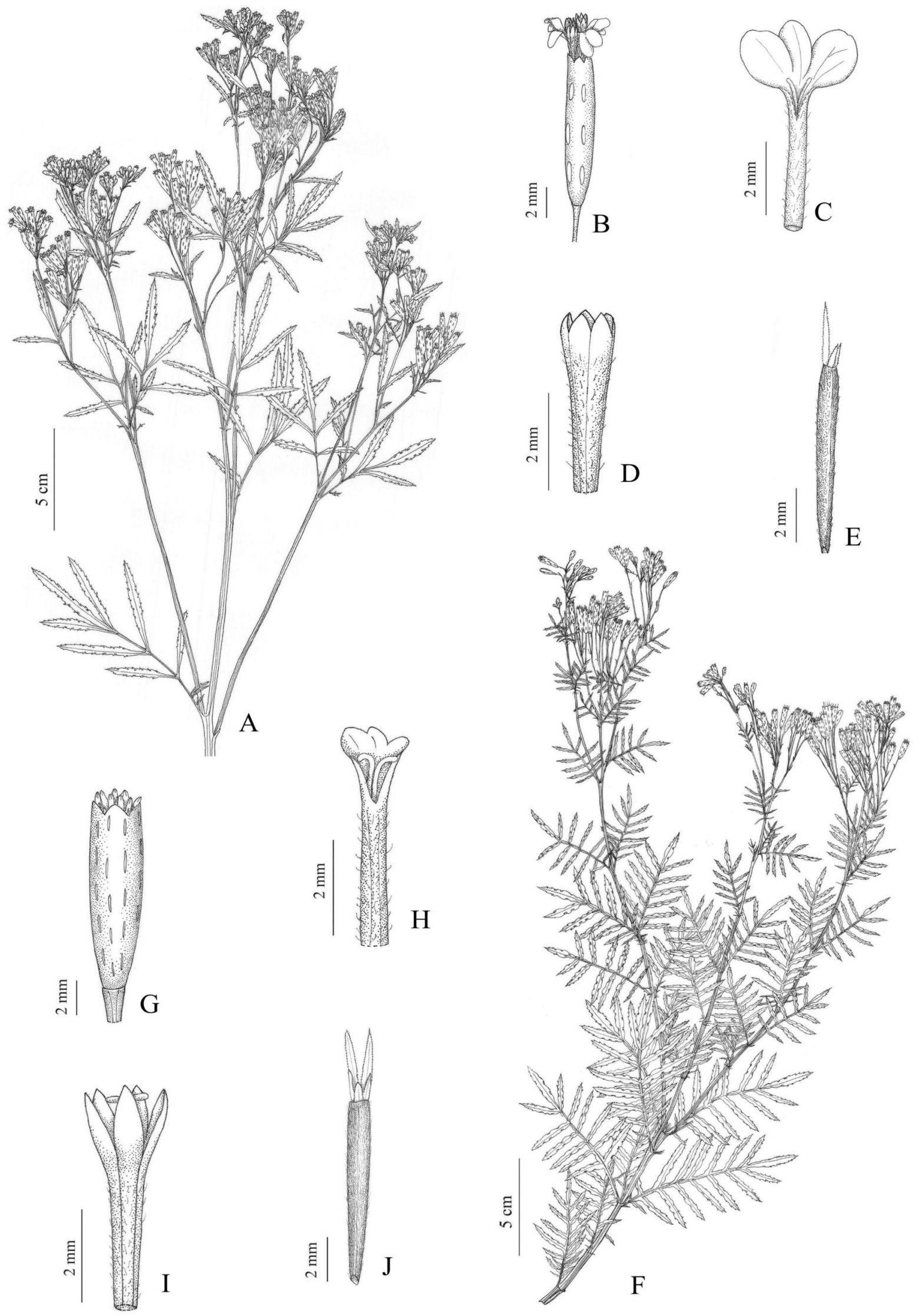

Figs. 5. A-J. A-E. Tagetes minuta L. A. Detalhe dos ramos; B. Capítulo; C. Flor ligulada do raio; D. Flor tubulosa do disco; E. Cipsela e pápus (A. O.S. Ribas et al. 6806 MBM. B-E. C.R. Carneiro 61 ICN). F-J. Tagetes osteni Hicken. F. Detalhe dos ramos; G. Capítulo; H. Flor ligulada do raio; I. Flor tubulosa do disco; J. Cipsela e pápus (F. M.R. Ritter \& A. Schneider 1400 ICN; G-J. C.R. Carneiro 16 ICN). 
Nordeste e Norte (Pará). Distribui-se também em outros países da América do Sul: Argentina, Chile, Paraguai e Uruguai (Zuloaga et al. 2014), Bolívia e Peru (Soule 1993). Habitat: em áreas alteradas, como lavouras e beiras de estradas (segundo observações de campo, etiquetas de exsicatas e Lorenzi 2000).

Observações: floresce e frutifica o ano todo, com predominância no outono, nos meses de abril e maio. É conhecida pelos nomes populares rabo-de-rojão, vara-defoguete, vareta-de-rojão, chinchila, cinchilho, guizo-decascavel, mata-pulgas e cravo-de-defunto.

Segundo Petenatti \& Ariza-Espinar (1997), a espécie é nativa da América do Sul, mas estende-se atualmente desde o sudeste dos Estados Unidos até o norte da Patagônia. Além disso, é introduzida na África do Sul, Austrália e no sul da Europa. É cultivada em diversas partes do mundo para extração de óleos essenciais.

De acordo com os critérios da IUCN, a espécie classificase como "pouco preocupante" (LC), pois é amplamente distribuída e ruderal, ocorrendo em áreas alteradas.

Devido à presença de compostos químicos secundários nas glândulas, Tagetes minuta apresenta diversas aplicações: na medicina popular, como diurética, para reumatismo, para expelir vermes intestinais e estimular o fluxo menstrual, para bronquites, tosses, resfriados, gota, nevralgias, dores lombares e inflamações articulares (Lorenzi \& Matos 2008); como inseticida, repelente, fungicida, bactericida, nematicida, etc., havendo diversos trabalhos que investigam ou testam o potencial de seus extratos, como no controle do mosquito Aedes aegypti L. (Furtado et al. 2005).

Material selecionado: ARGENTINA, BUENOS AIRES, Buenos Aires, Nueve de Julio, Ruta 5, 26.V.1979, $R$. Guglianone 245 (MBM). CORRIENTES, Corrientes, Escuela de Agricultura, 26.VI.1975, J.I. Maidana 9 (MBM). BRASIL, BAHIA, Miguel Calmon, 11'21'33'S, $40^{\circ} 33^{\prime} 52^{\prime}$ W, estrada Miguel Calmon-Cabeceiras, a $16 \mathrm{~km}$ de Miguel Calmon, 6.IV.2001, T. Ribeiro et al. 144 (MBM). MINAS GERAIS, Vargem Bonita, Pingador, $27^{\circ} 00^{\prime} 00,00^{\prime \prime}$, 5 5 ${ }^{\circ} 50$ '24,00"O, 11.IV.2011, A. Korte 6536 (FURB). PARANÁ, Araucária, Jardim Plínio, 19.V.2010, L.R. Lirola et al 01 (MBM); Campo Magro, Estrada do Cerne, $25^{\circ} 15^{\prime} 33,7^{\prime \prime} \mathrm{S}, 49^{\circ} 34^{\prime} 27,4^{\prime \prime} \mathrm{W}$, 20.IV.2008, A.R. Silva et al. 669 (HCF); Paranaguá, V.1973, M.M. Vernalha $s / n^{\circ}$ (UPCB 9357); Pitanga, 245' $45,3^{\prime \prime}$, 514'ㄹ'26,1”W, 17.I.2013, C.R. Carneiro 43 (ICN); Ponta Grossa, 21.V.1978, P. Occhioni 8408 (ICN); Senges, Rio Itararé, 15.VI.1971, G. Hatschbach 26724 (MBM); Sertanópolis, margem do Rio Congonhas, 26.VI.1997, M.R.C. Paiva \& J.A. Ferreira $s / n^{\circ}$ (ICN 172487); Tunas do Paraná, 22.IV.2008, Parque Estadual de Campinhos, G. Weiss \& L.B. Cettina 31 (MBM). PERNAMBUCO, Ouricuri, estrada Ouricuri/Juazeiro - Via Santa Cruz a 63 $\mathrm{km}$ de Ouricuri, BR122, 26.V.1984, O.A. Salgado et al. 384 (HBR, MBM). RIO DE JANEIRO, Rio de Janeiro, Petrópolis, Pedro do Rio, Rocinha, 6.IV.1968, D. Sucre 2643 \& P.I.S. Braga 484 (HB). RIO GRANDE DO SUL,
Caçapava do Sul, 30³3'04,1''S, 5331'21,5”'W, estrada para a Pedra do Segredo, 25.I.2013, C.R. Carneiro 51 (ICN); Coronel Bicaco, Vila Diniz, em beira de estrada, 1.XI.1994, R. Kubo $s / n^{\circ}$ (ICN 160321); Flores da Cunha, estrada Otávio Rocha, 6.V.1984, R. Wasum et al. s/n ${ }^{o}$ (HUCS 57); Gaurama, Linha Tonello, 20.IV.1993, A. Butzke et al. $s / n^{o}$ (HUCS); Montenegro, Kappesberg, 11.IV.1945, A. Bruxel $S J s / n^{\circ}$ (PACA 29745); Osório, Estação Experimental de Maquiné, 23.VI.1989, N. Silveira 8156 (HAS); Pelotas, 31S 34' 45”, 52W 16' 14,1”, BR116, 03.V.2013, C.R. Carneiro 61 (ICN); São Francisco de Paula, Lajeado Grande, 19.IV.2003, R. Wasum 1896 (HUCS); São João do Polêsine, 27.V.2000, R. Záchia, G. Vendruscolo \& E. Bicca 4692 (SMDB); Soledade, ca. $5 \mathrm{~km}$ da cidade, na rodovia para Porto Alegre, 20.VI.1984, R. Frosi \& N. Model 227 (HAS); Tapes, Bela Vista, 12.VI.1984, R. Frosi \& N. Model 106 (HAS); Vacaria, Fazenda dos Cedros, 12.IV.1975, $R$. Wasum $s / n^{\circ}$ (PACA 109174). SANTA CATARINA, Abdon Batista, Invernadinha do

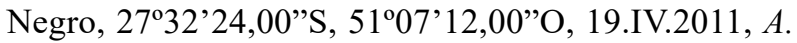
Korte 6721 (FURB); Araranguá, Sanga D'Anta, 27.V.1944, P.R. Reitz C603 (HBR); Capão Alto, Vigia, 2804'48,00”'s, 50³4'48,00”O, 3.V.2011, A. Korte, 6796 (FURB); Chapecó, Sede Trentim, 4.V.2006, S.M. Sabedot $s / n^{\circ}$ (ICN 144114); Lacerdópolis, Capinzal, 12.IV.1963, Reitz \& Klein 14681 (HBR); Palhoça, Campo Massiambu, 14.V.1953, Reitz \& Klein 629 (HBR); Siderópolis, São Bento, $28^{\circ} 37^{\prime} 12,00^{\prime \prime} \mathrm{S}, 49^{\circ} 35^{\prime} 24,00^{\prime} \mathrm{O}, 5 . \mathrm{XI} .2009$, M. Verdi et al. 2963 (FURB); Urubici, 2804'49,00”'S, 49²4'24,00”O, 3.IV.2009, M. Verdi et al. 1988 (FURB); Vitor Meireles, Serra Cambará, 265'35,00”S, 4951'47,00”O, 1.VI.2010, A. Korte \& A. Kniess 3527 (FURB). SÃO PAULO, Votuporanga, fazenda vizinha da Estação Experimental do IAC, 16.V.1995, Bernacci et al. 1657 (IAC). PARAGUAI, ALTO PARANÁ, Hernandarias, Reserva Tati Yupi, 7.VI.1988, N. Buttura 972 (MBM).

3.2 Tagetes osteni Hicken, Bol. Soc. Physis, 1(4): 181. 1913.

$$
\text { (Figs. } 5 \text { F-J; Fig. } 6 \text { J) }
$$

Ervas anuais eretas, 0,4-1,2 m alt., ginomonoicas, raiz pivotante, clara, muito ramificada; caule cilíndrico, estriado, ramificado, esverdeado. Folhas simples, sésseis, lâminas 2,7-7,6 x 1,7-4,5 cm, profundamente imparipinatissectas, contorno elíptico, base decurrente, ápice agudo, margem sinuada com porções serreadas, verde-claras, glabras ou glabrescentes (pouquíssimos pequenos tricomas junto à base dos jugos), glândulas oleíferas translúcidas pontuadoalongadas por toda a margem; 3-8 jugadas, segmentos 10-22 x 1,2-3,2 mm, linear-lanceolados. Sinflorescências terminais corimbiformes mais ou menos laxas, 3-10 capítulos. Capítulos radiados heterógamos; pedúnculos 3-15 mm compr., não engrossados no ápice; invólucro 8,511,7 x 2,7-4,6 mm, cilíndrico, 5-6 brácteas, ápice obtuso, glabras ou glabrescentes, verde-amareladas; receptáculo 0,75 mm diâm., convexo. Flores do raio 3-5, corola 3,2- 

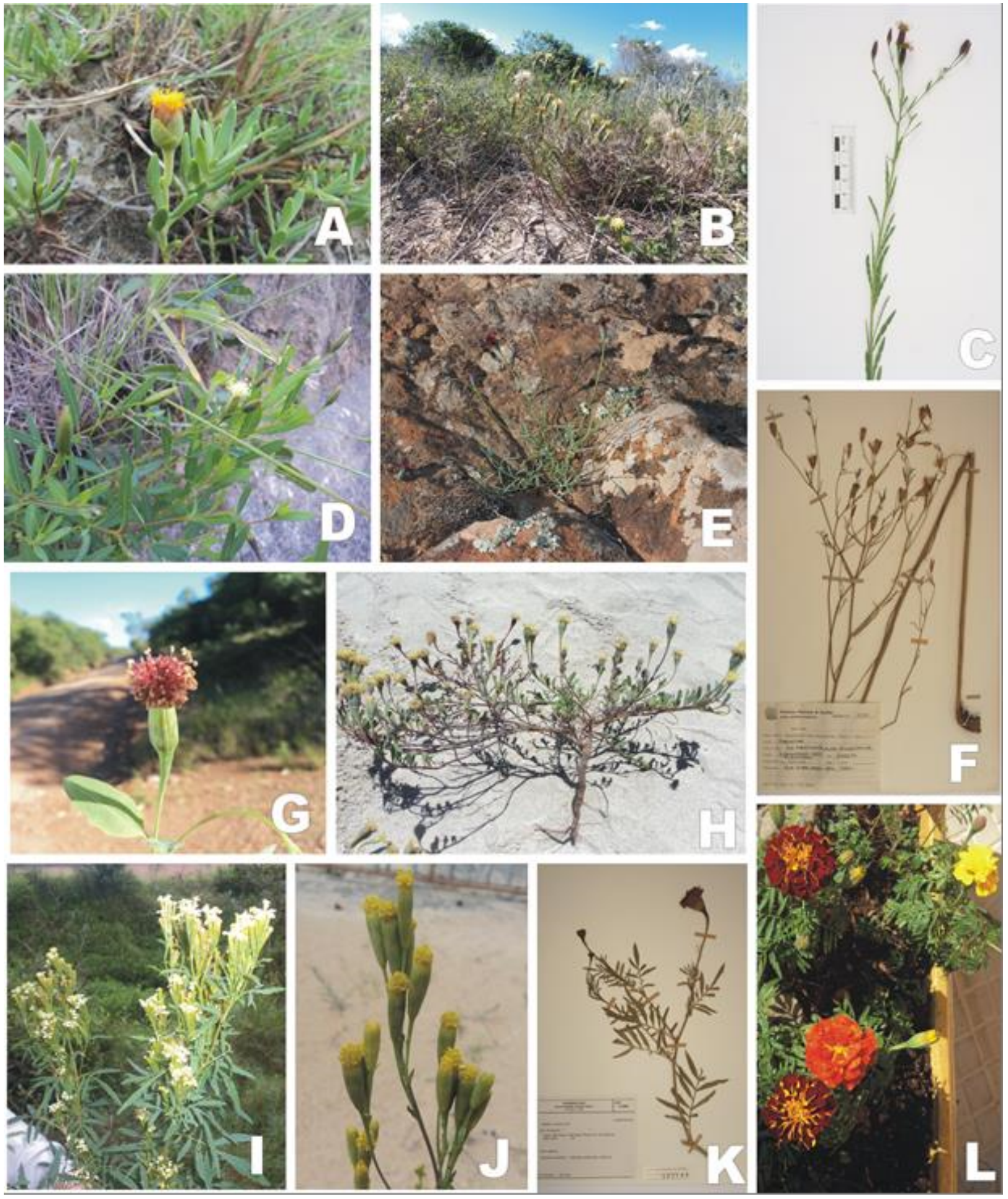

Figs. 6 A-L. A. Jaumea linearifolia, extremidade do ramo e capítulo; B. Porophyllum angustissimum, hábitat e hábito; C. Porophyllum curticeps, detalhe do ramo; D. Porophyllum lanceolatum, hábito; E. Porophyllum linifolium, hábito; F. Porophyllum obscurum, aspecto geral do exemplar MBM 17393; G. Porophyllum ruderale subsp. ruderale, capítulo e folha; H. Porophyllum spathulatum, hábito; I. Tagetes minuta, ramo com capítulos; J. Tagetes osteni, capítulos; K. Tagetes erecta, aspecto geral do exemplar MBM 201164; L. Tagetes patula, plantas em cultivo. Créditos das fotos: A-D, F-K. Camila Carneiro. E. Guilherme Seger.

4,6 mm compr., amarela, tubo coberto de tricomas, limbo $0,75-1,3 \times$ ca. $1 \mathrm{~mm}$, glabro, bilobado ou trilobado, lobos desiguais. Estilete ca. 3,5 mm compr., ramos ca. $0,9 \mathrm{~mm}$ compr., retos ou pouco recurvados, extremidade aguda ou arredondada. Flores do disco 8-12, 2,7-4,5 x ca. 1,1 mm, amarelas, tubo coberto de tricomas, lobos ca. 1 x $0,3 \mathrm{~mm}$, iguais. Anteras ca. 1,3 mm compr., amarelas, apêndice do conetivo agudo, apêndice basal truncado. Estilete ca. 3,6 mm compr., ramos 0,6-1 mm compr. Cipselas 6,8-7,5 $\mathrm{mm}$ compr., fusiformes, comprimidas, marrom-escuras, 
seríceas; carpopódio ca. $0,3 \mathrm{~mm}$, evidente. Pápus com 1 ou 2 aristas maiores, ca. 3,5 mm compr., 3 ou 4 aristas menores, 0,5-1,3 $\mathrm{mm}$ compr.

Distribuição geográfica: no Brasil, a espécie ocorre nos estados do Rio Grande do Sul e Santa Catarina, tendo sido encontrados, entre os materiais examinados, dois registros em diferentes cidades do litoral de São Paulo. No Uruguai, distribui-se pelos Departamentos de Rio Negro e Salto (Zuloaga et al. 2014).

Habitat: conforme observações de campo, a espécie ocorre em solos arenosos, sobretudo na região litorânea. Eventualmente também em solos pedregosos.

Observações: floresce e frutifica quase o ano todo (com exceção dos meses de inverno), com pico no outono, entre março e maio, formando aglomerados populacionais. A espécie teve a ocorrência citada para o sul do Brasil por Deble et al. (2005). Até então era considerada endêmica do Uruguai e os exemplares brasileiros eram identificados erroneamente como T. minuta. Diferencia-se desta por apresentar menor número de capítulos por sinflorescência, brácteas involucrais em número de cinco ou seis (em contraposição às três ou quatro de T. minuta), pelo maior número de flores no capítulo e consequentemente maior largura dos mesmos e também pelo menor tamanho das flores liguladas. Além disso, as folhas são menores (2,7-7,6 x 1,7-4,5 cm contra 4,5-13,5 x 3-8 cm em $T$. minuta), com segmentos mais delgados (10-22 x 1,2-3,2 mm contra $20-58 \times 1,9-10 \mathrm{~mm}$ em $T$. minuta), a cipsela possui indumento mais denso (serícea) e frequentemente ocorrem duas aristas longas no pápus (em T. minuta geralmente uma). Pode ser considerada, conforme os critérios da IUCN, como de "menor preocupação" (LC), pois apesar de não apresentar-se amplamente distribuída na área de estudo, forma grandes populações, ocorrendo em grande densidade em áreas perturbadas.

Material selecionado: BRASIL, RIO GRANDE DO SUL, Balneário Pinhal, 30¹4'14,8”S, 50¹5'3,7'W, dunas antes da chegada na cidade pela RS040, 5.10.2012, C.R. Carneiro 12 (ICN); Capão da Canoa, 15.XII.1991, I.A. dos Santos 1406 (MPUC); Farroupilha, 16.IV.1958, O. Camargo 1331 (PACA); Horizontina, interior, 20.IV.1975, L. Arzivenco $s / n^{\circ}$ (ICN 42737); Manoel Viana, RST 377 , km 351, 19.IV.2008, G. Bruisma 066 (ICN); Mostardas, 30³2'29,5”S, 50²5'06,7'W, Bacopari, 31.X.2012, C.R. Carneiro 14 (ICN); Osório, Lagoa dos Barros, 24.XI.1949, B. Rambo SJ 44530 (PACA); Palmares do Sul, 30¹7'52'S, 50²8'49'W, próximo ao Rio Bacupari, 19.IX.1994, N. Silveira 12626 (HAS); Porto Alegre, Praia do Cego, 8.V. 1971, J.C. Lindeman $s / n^{\circ}$ (ICN 8013); Rio Grande, $32^{\circ} 01^{\prime} 27,1^{\prime \prime} \mathrm{S}, 52^{\circ} 14^{\prime} 56,5^{\prime}$ 'W, próximo à Ilha da Torotama, 1.XI.2012, C.R. Carneiro 17 (ICN); Rosário do Sul, 3008'43,86'S, 54 $51^{\circ} 16,69^{\prime \prime} \mathrm{W}, 2^{\mathrm{a}}$ ponte na estrada Rosário-Cacequi, 7.XII.2012, C.R. Carneiro 24 (ICN); Santana do Livramento, 3049'40,7'S, 55'21'06,1"W, Cerro de Palomas, 22.I.2013, C.R. Carneiro 46 (ICN);
Terra de Areia, 27.VII.2002, C.F. Azevêdo-Gonçalves \& C.N.Gonçalves $s / n^{\circ}$ (ICN 127545); Torres, 29S 20' 46,20", 49W 45' 55,40”, Parque Estadual de Itapeva, próx. butiazal, 13.III.2013, C.R. Carneiro 55 (ICN); Viamão, 30S 22 ' 49,20", 51W 00'37,60", Parque Estadual de Itapuã, 20.III.2013, C.R. Carneiro 56 (ICN). SANTA CATARINA, Florianópolis, Ilha de Santa Catarina, Pontal do Daniela, 30.X.1987, M.L. Souza et al. 919 (FLOR, ICN, MBM); Garopaba, Siriú, 18.XI.1970, Klein \& Bresolin 9239 (HBR); Laguna, 28³6'26,3”S, 4851'22,9” W, Barra do Camacho, estrada de chão para Farol Sta. Marta, 06.IX.2012, C.R. Carneiro 4 (ICN); Sombrio, 3.I.1943, P.R. Reitz $s / n^{\circ}$ (HBR 544). SÃO PAULO, Cananéia, Parque Estadual da Ilha do Cardoso, Praia de Itacuruça, 17.IV.2005, F.O. Souza \& R.S. Bianchini 226 (SP); Ubatuba, 2.V.1961, Schultz 2973 (ICN).

\section{Espécies da Tribo Tageteae cultivadas na Região Sul do Brasil}

Tagetes erecta L. (Fig. $6 \mathrm{~K}$ ): nativa do México e América Central e naturalizada em muitos locais na América do Sul e no Velho Mundo (Rydberg 1915). Essa e outras espécies ornamentais do gênero são mundialmente cultivadas e conhecidas como "marigolds". T. erecta, especificamente, é conhecida como "African marigold" ou "tagete gigante". Além da importância ornamental, diversos trabalhos relatam ou testam as inúmeras atividades e usos de $T$. erecta: na medicina popular (principalmente no México), contra diarréia, vômito, dores gastrointestinais, cólica, flatulência, complicações do fígado, pé-de-atleta, inflamações e outras complicações (Heinrich 1996); como inseticida e nematicida, utilizada no controle biológico em culturas (Mertz 2009); como anti-helmíntica (Tonuci et al. 2012) e ainda como alimentícia, antioxidante, cosmética, etc.

Tagetes patula L. (Fig. 6 L): espécie nativa do México e da Guatemala e cultivada como ornamental em diversas partes do mundo. Conhecida popularmente como "tagete anão" ou "French marigold", é muito semelhante a $T$. erecta. Alguns autores, inclusive, consideram T. patula um sinônimo ou um cultivar de T. erecta (Lorenzi \& Souza 2008, Keil 2012).

As duas espécies diferem no porte (T. erecta tem maior porte, atingindo mais de $1 \mathrm{~m}$ de altura e $T$. patula tem em média $30 \mathrm{~cm}$ ), no tamanho e cor dos capítulos (T. erecta tem capítulos maiores, com invólucro 14-20 x 7-12 mm contra ca. 12 × 6-7 mm em $T$. patula, e com flores geralmente amarelas a alaranjadas, enquanto as flores de $T$. patula variam do amarelo até o vermelho ou marrom). Além disso, os pedúnculos de $T$. erecta são bastante dilatados no ápice, enquanto os de $T$. patula são pouco dilatados. T. patula também apresenta diversos usos: contra febre, vermes, complicações do fígado e estômago (Heinrich 1996), como antioxidante e analgésico (Faizi 2011), como corante de alimentos, devido aos carotenóides (Vasudevan et al.1997), entre outros. 
O Rio Grande do Sul revelou-se o Estado com maior riqueza em número de espécies nativas, apresentando todos os táxons levantados na área de estudo, seguido por Santa Catarina, com quatro espécies (Porophyllum curticeps, P. ruderale, Tagetes minuta e T. osteni) e Paraná, com apenas duas espécies ruderais (P. ruderale e T. minuta). $\mathrm{O}$ gênero de maior riqueza é Porophyllum, com sete espécies. Porophyllum curticeps foi taxonomicamente revalidada e a espécie foi circunscrita em relação à Porophyllum lanceolatum, da qual era considerada sinônimo anteriormente. A ocorrência de Porophyllum angustissimum, questionada por alguns autores, foi confirmada na área de estudo. Porophyllum obscurum não foi coletada, mas há coletas relativamente recentes, que confirmam a ocorrência do táxon na Região Sul do Brasil.

À exceção do gênero Porophyllum, pode-se dizer que a Região Sul não constitui um centro de diversidade importante para a tribo Tageteae. Mesmo assim, esses representantes merecem atenção, pois se encontram ameaçados em função da diminuição e fragmentação de habitat, havendo cada vez menos ambientes campestres naturais disponíveis, sobretudo nos estados do Paraná e Santa Catarina, onde os campos naturais já são restritos e tornam-se ainda mais raros pelo avanço das monoculturas.

O gênero taxonomicamente mais problemático é Porophyllum, persistindo ainda dúvidas quanto à circunscrição das espécies e a necessidade de estudos aprofundados, aliando outras técnicas à taxonomia clássica, sobretudo as moleculares.

\section{AGRADECIMENTOS}

Os autores agradecem à Anelise Scherer de Souza Nunes pelas ilustrações, à Márcia Vignoli da Silva pela ilustração de Porophyllum spathulatum, à Ana Carolina Oliveira da Costa pelas fotografias de detalhes e a Edson Luís de Carvalho Soares pela diagramação das ilustrações. Agradecemos também a Guilherme Dubal dos Santos Seger, Karen de Araújo Freitas, Eduardo Pasini e Sérgio Bordignon pela cessão de imagens. O primeiro autor agradece ao Programa de Pós Graduação em Botânica da Universidade Federal do Rio Grande do Sul pelo auxílio financeiro para as expedições ao campo. Esse artigo é a contribuição número 11, apoiado pela CAPES/PNADB através do projeto "Conhecimento, uso e conservação da biodiversidade de plantas na Mata Atlântica e Caatinga" (UFSC/ UFRPE/UFRGS).

\section{REFERÊNCIAS}

Baldwin, B.G. 2009. Heliantheae alliance. In Systematics, Evolution and Biogeographics of Compositae (V.A. Funk, A. Susanna, T.F. Stuessy \& R.J. Bayer, eds.). International Association for Plant Taxonomy, Vienna, p. 689-711.

Baldwin, B.G., Wessa, B.L. \& Panero, J.L. 2002. Nuclear rDNA evidence for major lineages of Helenioideae Heliantheae (Compositae). Systematic Botany 27:161-198.

Beentje, H. 2010. The Kew Plant Glossary. Royal Botanic Gardens, Kew. 160 p.
Bentham, G. 1873. Compositae. In Genera Plantarum (G. Bentham \& J.D. Hooker). Lovell Reeve \& Co., London, v. 2, part. 1, p. 163-533.

Bremer, K. 1994. Asteraceae - cladistics and classification. Timber Press, Portland. 752 p.

Brummitt, R.K. \& Powell, C.E. (eds.). 1992. Authors of plant names. Royal Botanic Gardens, Kew. 732 p.

Cabrera, A.L. 1974. Compuestas. Tribu VI. Helenieae. In Flora Ilustrada de Entre Ríos (A. Burkart, ed.) . I.N.T.A., Buenos Aires, v. 6, p. 399-415.

Carneiro, C.R. 2018. Porophyllum In Flora do Brasil 2020 em construção. Jardim Botânico do Rio de Janeiro. Disponível em: <http:// floradobrasil.jbrj.gov.brreflora/floradobrasil/ FB16259>. Acessado em 12 jun. 2018.

Carneiro, C.R. \& Ritter, M.R. 2016. Lectotypifications in Brazilian Porophyllum (Asteraceae: Tageteae). Phytotaxa 278(1):62-64.

Carneiro, C.R., Schneider, A.A. \& Ritter, M.R. 2014. Porophyllum spathulatum (Asteraceae: Tageteae), a new species from the southern Brazilian coast. Phytotaxa 173(2):157-162.

Cassini, H. 1816. Tableau exprimant les affinities des tribus naturelles de famille des Synanthérées, suivant la methode de classification de M. Henri Cassini. In Dictionnaire des sciences Naturelles (G. Cuvier, ed Le Normant, Paris, .) v. 3. p. 179.

1819. Sixième memoire sur la famille des Synanthérées, contenant les caractères des tribus. Journal de Physique, de Chimie, d'Histoire Naturelle et des Arts 88: 150-163,189-204.

Cordazzo, C.V., Caetano, V.L. \& Costa, C.S.B. 2007. Jaumea linearifolia (Juss.) DC. (Asteraceae), primeiro registro para o Brasil. Iheringia. Série Botânica 62(1-2): 99-102.

Deble, L.P.,Oliveira, A.S. \& Marchiori, J.N.C. 2005. Tagetes osteni Hicken, citação nova para a flora sul-brasileira. Balduinia 2:4-6.

Faizi, S., Dar, A., Siddiqi, H., Navi, S., Naz, A. \& Bano-Lubna, S. 2011. Bioassay guided isolation of antioxidant agents with analgesic properties from flowers of Tagetes patula. Pharmaceutical Biology 49(5):516-525.

Font Quer, P. 1979. Diccionario de Botânica. Editorial Labor S.A., Barcelona. $1.244 \mathrm{p}$.

Fortes, A.B. 1959. Geografia física do Rio Grande do Sul. Globo, Porto Alegre. 393 p.

Funk, V.A., Susanna, A., Stuessy, T.F. \& Bayer, R.J. (eds.). 2009. Systematics, Evolution and Biogeographics of Compositae. International Association for Plant Taxonomy, Vienna. $965 \mathrm{p}$.

Furtado, R.F., Lima, M.G.A., Andrade Neto, M., Bezerra, J.N.S. \& Silva, M.G.V. 2005. Atividade larvicida de óleos essenciais contra Aedes aegypti L.(Diptera: Culicidae). Neotropical Entomology 34(5):843-847.

Gandhi, K.N. \& Thomas, R.D. 1989. Asteraceae of Louisiana. Sida, Bot. Misc. 4:1-202

Gonçalves, E.G. \& Lorenzi, H. 2007. Morfologia Vegetal: organografia e dicionário ilustrado de morfologia das plantas vasculares. Instituto Plantarum, Nova Odessa. 416 p.

Harris, J.G. \& Harris, M.W. 2001. Plant Identification Terminology. An Illustrated Glossary. Second Edition. Spring Lake Publishing, Utah. 205 p.

Heinrich, M. 1996. Ethnobotany of Mexican Compositae: an analysis of historical and modern sources. In Compositae: Biology \& Utilization. Proceedings of the International Compositae Conference (P.D.S. Caligari \& D.J.N. Hind, eds). The Royal Botanic Gardens, Kew, v. 2, p. 475-503.

Howard, R. A. 1989. Compositae. In Fl. Lesser Antilles (R.A. Howard, ed.). 6:601.

International Plant Names Index -IPNI 2014. Disponível em: http:// www.ipni.org. Acessado em: 08.02.2014

Internacional Union for Conservation of Nature - IUCN. 2013. The IUCN Red List of Threatened Species, version 2013.2. Disponível em: http://www.iucnredlist.org. Acessado em 26.01.2014.

Johnson, R.R. 1969. Monograph of the Plant Genus Porophyllum (Compositae-Helenieae). The University of Kansas Science Bulletin 48(7):225-267.

Keil, D.J. 2012. Tagetes. In Jepson eFlora (Jepson Flora Project, ed.). Disponível em: http://ucjeps.berkeley.edu/cgi-bin/get_IJM. pl?tid $=5193$. Acessado em 22.02.2014.

Lombardo, A. 1983. Flora Montevidensis. Tomo II Gamopétalas. Servicio de Publicaciones y Prensa, Montevideo, p. 257-263. 
Lorenzi, H. 2000. Plantas daninhas do Brasil: terrestres, aquáticas, parasitas e tóxicas. 3 ed. Instituto Plantarum, Nova Odessa. 608 p.

Lorenzi, H. \& Matos, F.J.A. 2008. Plantas medicinais no Brasil: nativas e exóticas. 2 ed. Instituto Plantarum, Nova Odessa. 544 p.

Lorenzi, H. \& Souza, H.M. 2008. Plantas ornamentais no Brasil: arbustivas, herbáceas e trepadeiras. 4 ed. Instituto Plantarum, Nova Odessa. 1088 p.

Malme, G.O.A. 1899. Die Compositen de Ersten Regnellschen Expedition. Kongliga Svenska Vetenskaps 32(5):1-90.

. 1931. Die Compositen der zeeiten Regnellschen Reise. I. Rio Grande do Sul. Arkiv för Botanik 24(6):1-89.

Mertz, N.R. 2009. Controle biológico do pulgão Aphis gossypii Glover (Hemíptera: Aphidae) em cultivo protegido de pepino com cravode-defunto (Tagetes erecta). Dissertação 54 f. Universidade Federal de Lavras, Lavras.

Panero, J.L. 2007a. Key to tribes of the Heliantheae Alliance. In The Families and Genera of Vascular Plants, Flowering Plants. Eudicots. Asterales (J.W. Kadereit \& C. Jeffrey, eds.). Springer, Berlin, v. 8, p. 391-395.

. 2007b. Tageteae. In The Families and Genera of Vascular Plants, Flowering Plants. Eudicots. Asterales. (J.W. Kadereit \& C. Jeffrey, eds.). Springer, Berlin, v. 8, p. 420-431.

Petenatti, E.M. \& Ariza-Espinar, L. 1997. Asteraceae, Tribu VI. Helenieae. In Flora Fanerogámica Argentina 45 (A.T. Hunziker, ed.) Programa Proflora (CONICET), Córdoba., parte 6, p. 1-34.
Roque, N. \& Bautista, H. 2008. Asteraceae - Caracterização e Morfologia Floral. Editora da Universidade Federal da Bahia, Salvador. 69 p.

Rydberg, P.A. 1915. (Carduales) Carduaceae: Helenieae, Tageteae. North American Flora 34(2):81-180.

Soule, J.A. 1993. Tagetes minuta: A potential new herb from South America. In New crops. (J. Janick \& J.E. Simon, eds.). Wiley, New York, p. 649-654.

Thiers, B. 2015[continuamente atualizado]. Index Herbariorum: A global directory of public herbaria and associated staff. New York Botanical Garden's Virtual Herbarium. Disponível em: http: //sweetgum.nybg. org/ih/. Acessado em 20.12.2015.

Tonuci, L.R.S., Melo, N.I., Dias, H.J., Wakabayashi, K.A.L., Aguiar, G.P., Aguiar, D.P., Mantovani, A.L.L., Ramos, R.C., Groppo, M., Rodrigues, V., Veneziani, R.C.S., Cunha, W.R., Silva Filho, A.A., Magalhães, L.G. \& Crotti, A.E.M. 2012. In vitro schistosomicidal effects of the essential oil of Tagetes erecta. Revista brasileira de farmacognosia 22(1): 88-93.

Vasudevan, P., Kashyap, S. \& Sharma, S. 1997. Tagetes: A multipurpose plant. Bioresour Technol 62: 29-35.

Zuloaga, F.O., Morrone, O. \& Belgrano, M.J. (eds). 2014. Catálogo de las Plantas Vasculares del Cono Sur (Argentina, Sur de Brasil, Chile, Paraguay y Uruguay). Disponível em: http: //www2.darwin. edu.ar/Proyectos/FloraArgentina/FA.asp. Acessado em 20.02.2014. 